\title{
How to access ancient landscapes? Field survey and legacy data integration for research on Greek and Roman settlement patterns in Eastern Sicily
}

The integration of field survey data from Eastern Sicily (the Plain of Catania) with legacy data available for the region will expand our knowledge on Mediterranean ancient rural landscapes. With an extent of $430 \mathrm{~km} 2$, the area is a perfect case study due to its geographical unity and the number of archaeological projects (both excavations and surveys) carried out within it in recent decades. Indeed, combining data from earlier research projects with new archaeological survey data allows us to conduct a settlement pattern analysis of the project's study area. Heterogenous datasets have been integrated through their implementation into a geo-database, featuring the management and integration of topographical units and archaeological entities through semantic relations. Through geospatial data analysis based on the complete gazetteer of archaeological sites (whether sherd scatters, ruins, caves dwellings, tombs or tracks), a new image of rural landscapes for this area of Eastern Sicily from the Greek Archaic to the Late Roman Age can be visualized, beyond the traditional Sicilia frumentaria narrative.

\section{Introduction}

The research seeks to outline the main developments in settlement organization in the Plain of Catania (Sicily's most extensive at $430 \mathrm{~km}^{2}$ ) and its surroundings, from the Archaic to the Late Roman period (Fig. 1). The area makes for a perfect case study due to the number of excavation and survey projects carried out within it over the last few decades (Fig. 2). The Plain is located in the interior of the Ionian-Etnean region, its geographical limits being the Etna Volcano to the north, the Hyblean Plateau to the south and the wide extension of the Erean Mountains to the West (Fig. 3). The plain originated in the alluvial deposits of the Simeto, Dittaino, Gornalunga and San Leonardo rivers', which cross it through an East to West axis towards the Ionian Sea, and there formed a low sandy coast ${ }^{2}$.

1 Monaco et al. 2000, 2004; Carbone, Branca, Lentini 2009.

2 For ancient toponyms, see Manni 1981, 103, 106, 123. 

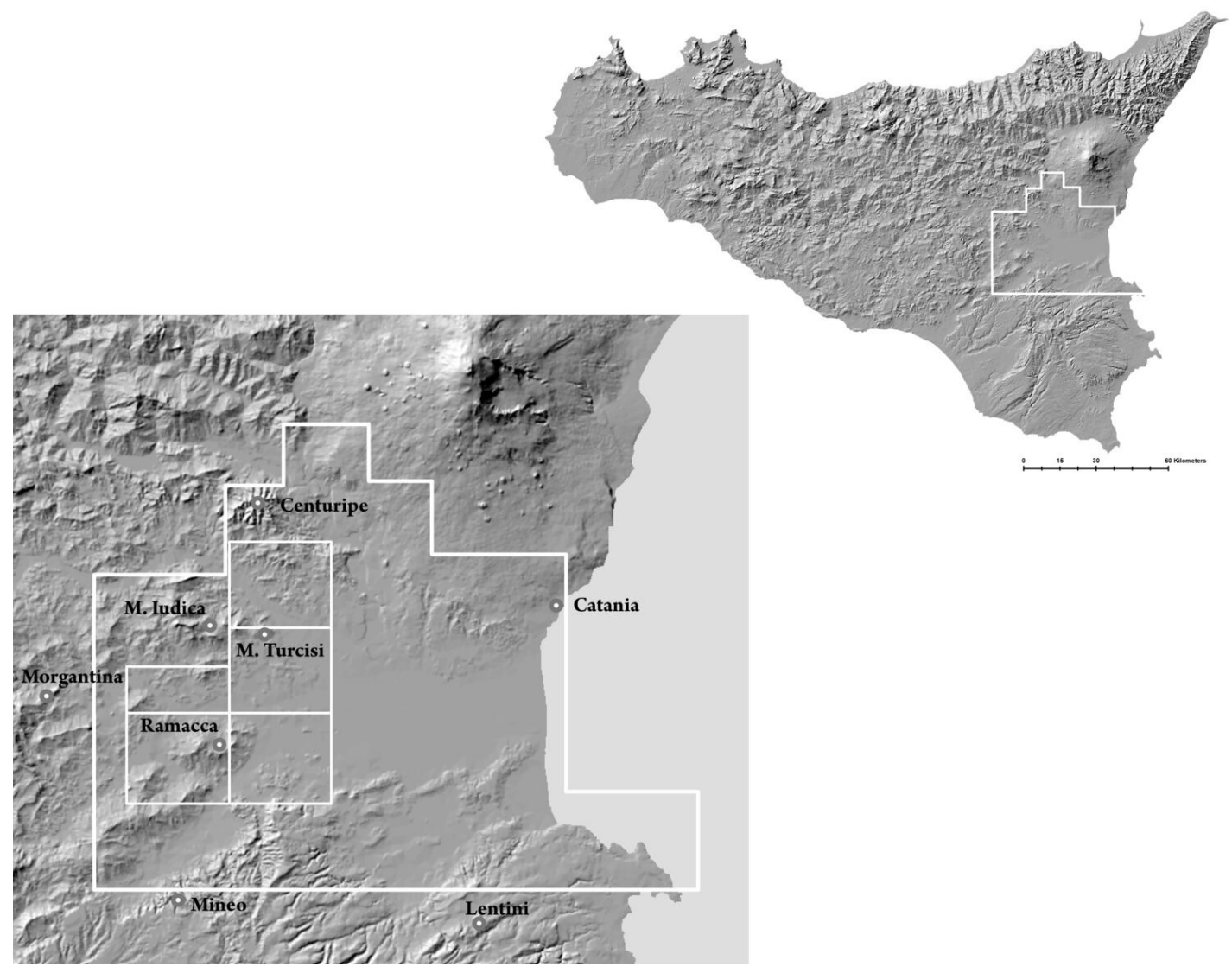

The rural landscape of Eastern Sicily is not one of the most intensively studied in the Mediterranean. Although archaeologists have documented plenty of settlements, cemeteries, monuments, artefacts scatters and other landscape features for over a century, the resulting data are still limited in quantity and variable in quality. This problem is particularly prevalent in the countryside of the IonianEtnean region since archaeological studies here have traditionally favoured urban over rural landscapes, and this has only recently begun to be redressed ${ }^{3}$. Indeed, the territory of Leontinoi/Lentini ${ }^{4}$, as well as that of Katane/Catina/Catania, Morgantina/Aidone and Kentoripa/Centuripe, was located around the alluvial plain: a few scholars have focused it in the context of the political edges of each political entity, but not its role in economis and settlement patterns dynamics 5 .

Research interest in the archaeology of the Plain of Catania accelerated at the end of 1980s, but the first attempt at systematic research on the region's rural landscapes

3 Arcifa 2001; Albanese Procelli et al. 2007; Bonacini 2007; Sirena 2011, 2012; Malfitana, Cacciaguerra 2011; Brancato 2019; Brancato, Caliò 2019; Brancato 2020a-b.

4 Frasca 2009.

5 For the Greek age see Holm 1896-1906, 99-100; Dunbadin 1948, 129-134; Procelli 1989; Manganaro 1996; De Angelis 2016; for the Roman age, Bejor 1986; Wilson 1990; Pfuntner 2019; de Ligt 2019. 


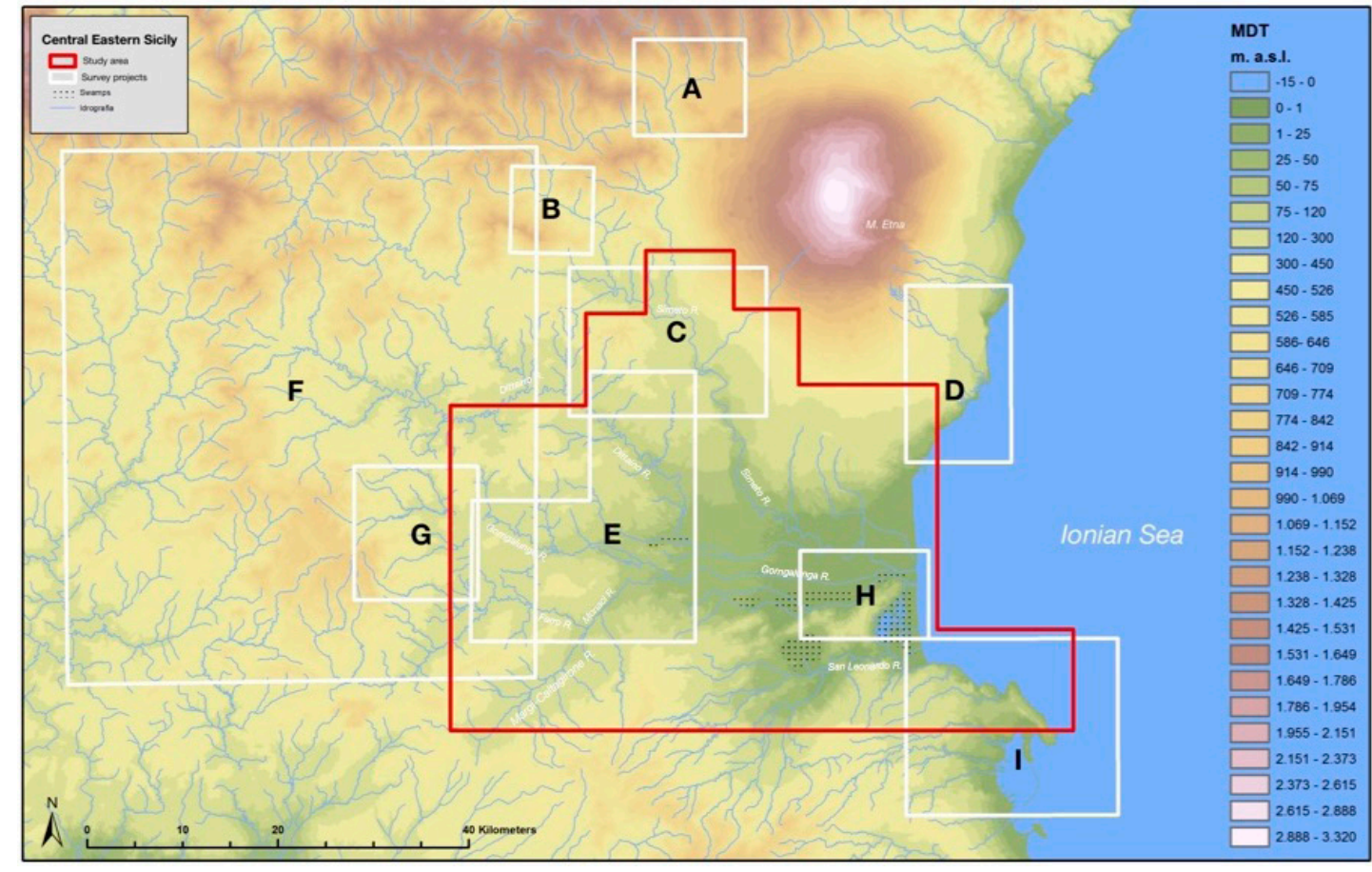

started only in the mid $1990 s^{6}$. The quantity of legacy data available for the Plain of Catania and its surroundings offers a real contribution to bridging the knowledge gap of settlement patterns and rural landscape changes in Eastern Sicily ${ }^{7}$. Using it for new archaeological landscape research is necessary due to the changing nature of the surface archaeological record, the impact of the environmental degradation on it, and finally due to the paucity of regional survey results available for this part of the island ${ }^{8}$. Simply put, old reports of surface finds may be the only surviving record of past activity in rural landscapes. Another element that makes the use of legacy data necessary for any landscape study in Sicily is the general sparsity of data on rural archaeological landscapes, a problem likely related to the tradition focus of archaeological studies on the ancient coastal settlements and to a simplistic view of the structure of the agricultural production in antiquity.

The use of archaeological survey data for evaluation of landscape dynamics is concerned with the distribution of settlements and changes in number of recorded sites over time? ${ }^{9}$ By relating intensive survey projects results to legacy data available for the research area, it is possible to quantify shifts in the use of specific environments on a regional scale, allowing us to model and visualize settlement dynamics over time. Here the results of a semantic integration approach applicated
Fig. 2. Sicily, Central-Eastern Sicily, research limits of archaeological field survey projects carried out in the area: A) upper Simeto Valley Project (Leone, Witcher 2007); B)

Troina survey (Ayala, French 2003, 2005); C) Centuripe, archaeological map (Biondi 2002); D) Catania, archaeological map of the city (Tortorici 2016) and of territory (Tortorici 2002;

Tortorici, Brancato in press); E) field survey of Gornalunga river valley (Albanese

Procelli et al. 2007; Tortorici 2015;

Brancato 2018); F) Erean Mountains

Survey (Giannitrapan 2017); G) Morgantina survey (Thompson 1990; Leighton 2005); H) Field survey of the centraleastern sector of the Plain of Catania (Brancato, Manganelli 2017); I) Augusta, archaeological map (Lanteri 1997; Malfitana, Cacciaguerra 2011).

6 Privitera, Spigo 2005; Bonacini 2007.

7 Allison 2008; De Felici, Sibilano, Volpe 2008.

8 Burgio 2017.

9 On ancient landscape dynamics and diachronic comparisons of distribution patterns of Greece see Alcock 1993, Bintliff 1997; Farinetti 2011. 
Fig. 3. Sicily, Ramacca: view on the Plain of Catania from the South; Monte ludica and Monte Turcisi are visible on the horizon

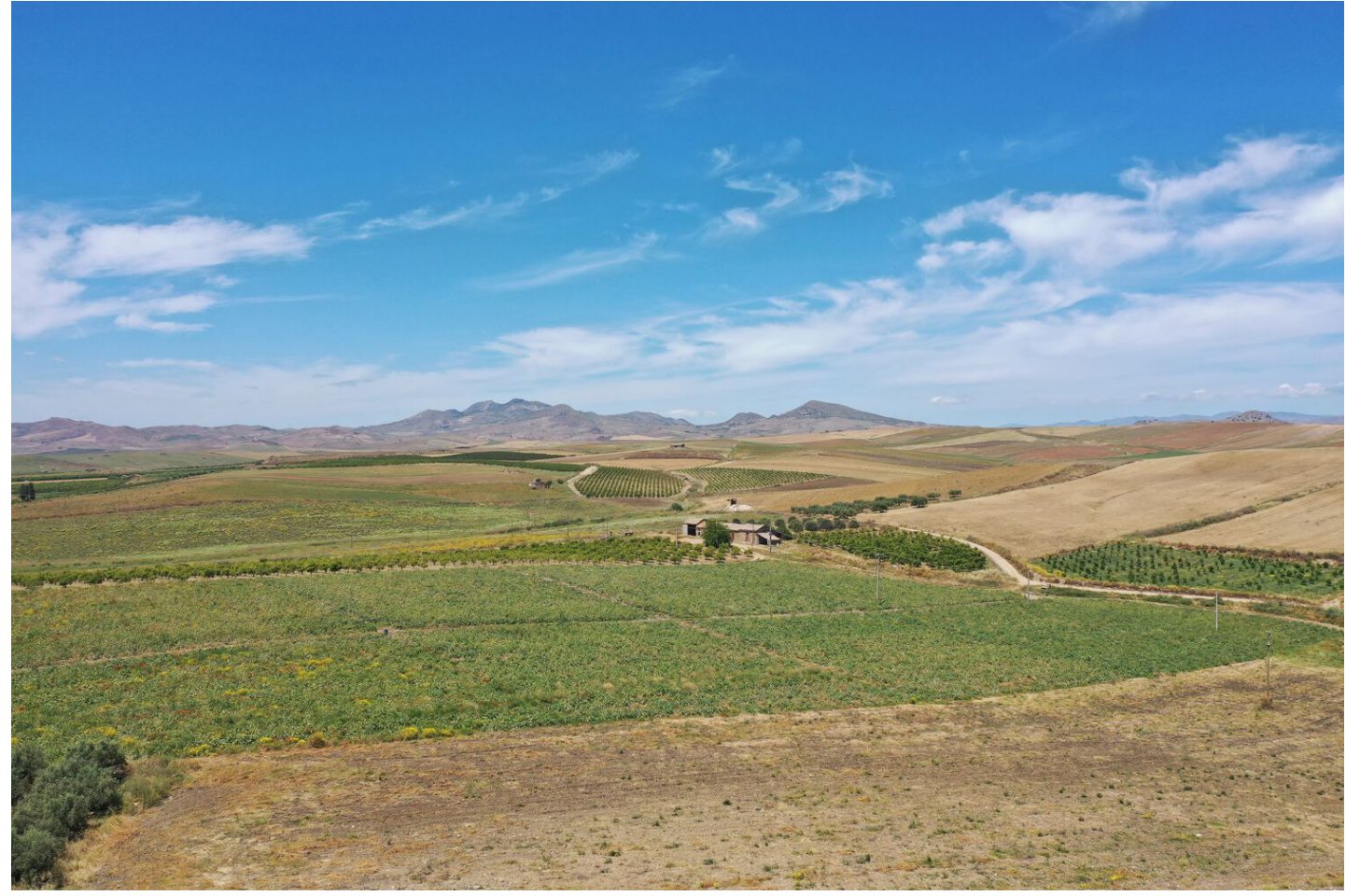

to the analysis of survey-based legacy data is presented, which may allow further assessments of the spatial configuration of possible land-use areas ${ }^{10}$. The field work (1997-2007) consisted of archaeological surveys carried out according to the Forma Italiae Project's methodology": mostly covering the western portion of the plain of Catania ( $476 \mathrm{~km} 2)$, due to their unexploited potential, these topographical surveys are of considerable interest in any attempt to analyse rural landscapes and route networks in antiquity ${ }^{2}$.

\section{Methodology}

The use of legacy data for archaeological landscape research is a theme which has been widely considered in archaeology in the last decade ${ }^{13}$. In order to reach a clear understanding of the taphonomic processes that shaped the Plain of Catania's

10 For a possible approach, see Bonnier, Finné and Weiberg 2019.

11 Marchi 2014.

12 The intensive and systematic field survey, led by E. Tortorici (Catania University) with the support of Dr. E. Procelli, was carried out during the decade 1997-2007 in the territory of Palagonia, Ramacca and Castel di Iudica on the western edges of the Plain of Catania; the cartographic base consisted of 1: 25,000 scale IGM tablets (F. 269 I SO Sferro, F. 269 II NO Monte Turcisi; F. 269 II SO La Callura, F. 269 III NE Castel di Iudica-southern sector, F. 269 III SE, Ramacca). Preliminary reports of the field survey are in Albanese Procelli et al. 2007; Sirena 2011, 2012; Tortorici 2015.

13 Witcher 2008; Vermeulen 2012. 


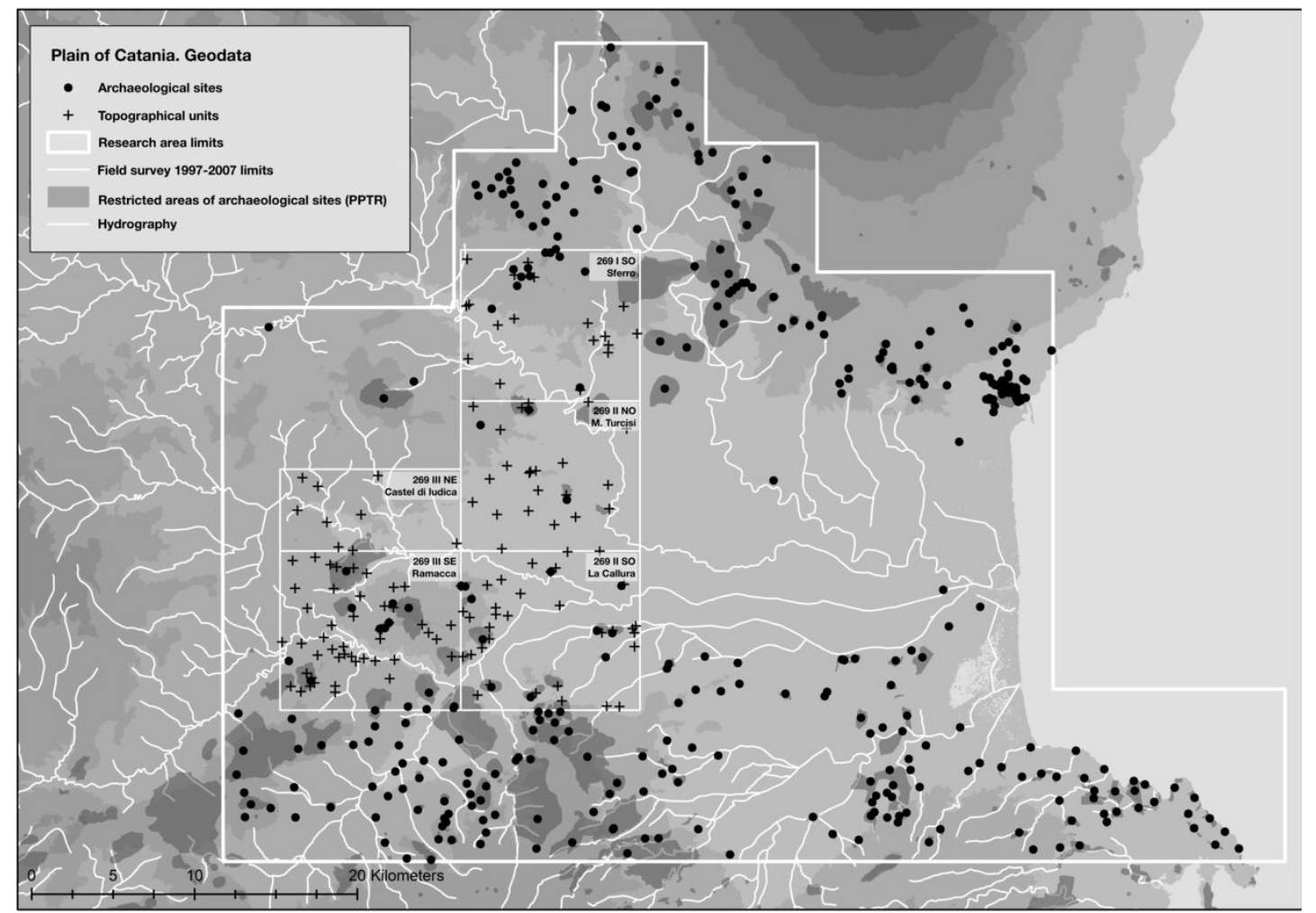

Fig. 4. Sicily, Plain of Catania: topographical units and archaeological sites within the research area limits.

ancient landscapes from the Greek to the Late Roman Age, we need to reassess the available archaeological data in the light of literary evidence, epigraphy and numismatics (fig. 4). Furthermore, scrutiny of cartography, aerial photography and satellite imagery is necessary in order to interpret this level of archaeological data as traces of ancient rural landscapes bound up with settlement dynamics and route networks ${ }^{14}$.

During the data collection process all periods that have left traces in the area were considered, as the transformations of landscapes can only be clearly understood through a long-term perspective ${ }^{15}$.

The datasets created through the digitization process are based on:

- archaeographic data from the field surveys project on the western edges of the Plain of Catania (1997-2007) ${ }^{16}$ (fig. 5);

14 Vermeulen 2012.

15 Belvedere, Bergemann 2019; see also Concannon, Mazurek 2016.

16131 topographic units (hereafter UT) were identified during the field survey largely consisting of artefacts scatters, buildings and rock-cut graves cemeteries spanning from the Prehistory to the Modern Age: each UT was identified with a polygon depicted in cartography IGM tablets and decribed in a catalog card where geographic coordinates (at least 4 couples), toponym, municipality, visibility and land-use were indicated. The fieldwork produced a substantial amount of archaeological data: from the surveyed areas, 2753 pottery sherds were collected, classified and identified (fabrics and attributes of forms, profile types, decorative techniques and 
Fig. 5. Sicily, Plain of Catania: archaeological map of the western edges of the area (cartographic bases: IGM F. 269 S.O. Sferro; F. 269 II N.O. Monte Turcisi; F. 269 II S.O. La Callura; F. 269 III N.E. Caste di ludica, southern sector; F. 269 III S.E. Ramacca).
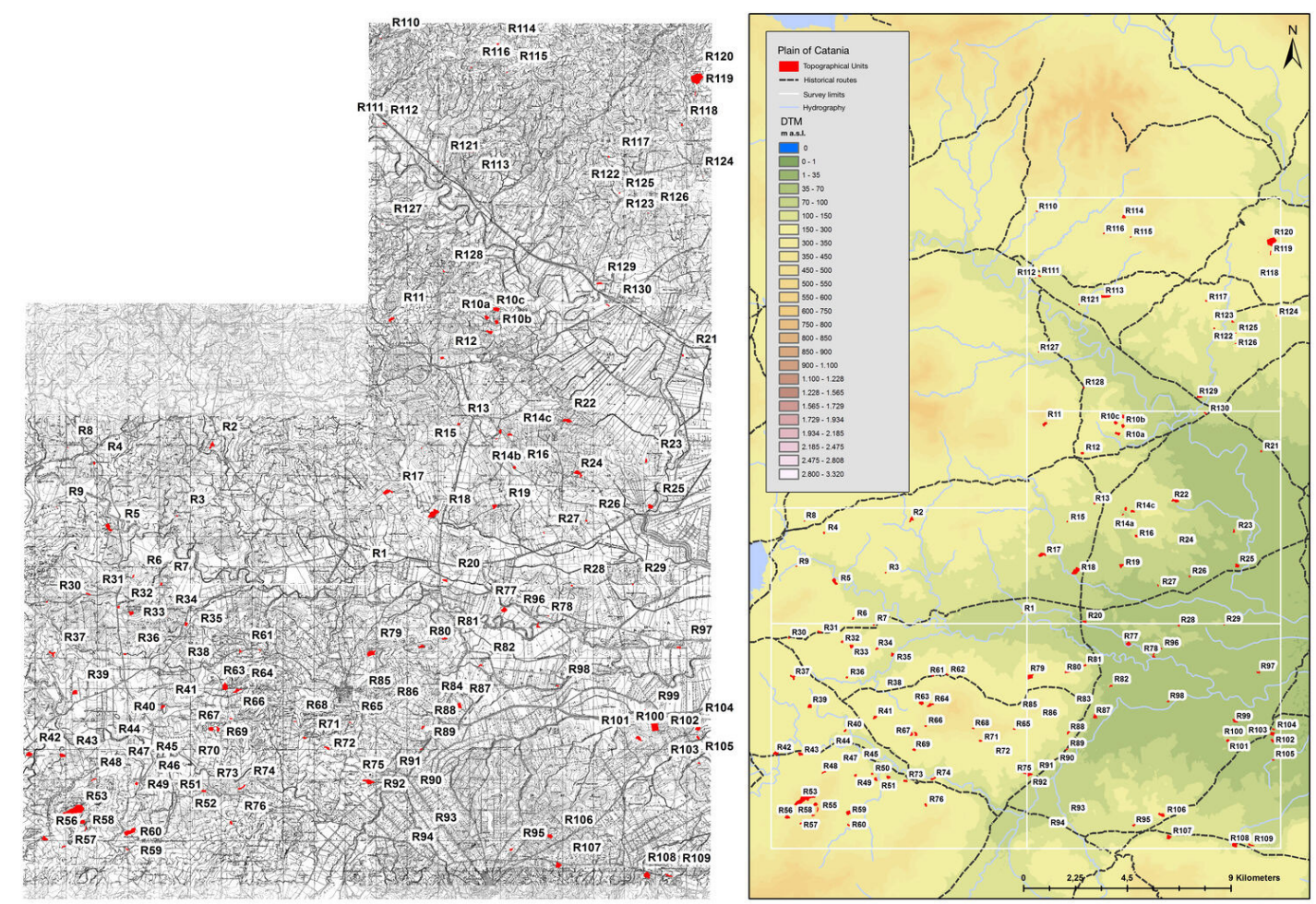

- published reports of archaeological excavations and survey projects carried out in the study area ${ }^{17}$;

- archaeological sites gazetteers and archive catalogues created by the local cultural heritage institutions (Soprintendenze di Catania, Enna e Siracusa);

- topographical data obtained from the field-work planned for the georeferencing of legacy data in points 2 and 3 (i.e. archaeological sites whose position was not previously clearly determined) ${ }^{18}$.

motifs were recorded) and considered to be diagnostic if they possessed at least a rim or basis profile and/or any surfaces decoration. Ceramic sherds were quantified according of each type defined in the type series: The Estimated Vessel Equivalent (EVE) was based on rim percentage, recorded using a rim chart (Orton and Hughes 2013, 21-22); on sherds fragmentation and quantification issues in field survey archaeology see Terranato 2004, 40-42; on quantification in general see Orton 1993; Hawthorne 1996.

17 Lanteri 1997; Valenti 1992, 1997-98; Thompson 1999; Biondi 2002; Malfitana, Cacciaguerra 2011.

18 Several sets of polygon and point data were collected between November 2016 to late July 2018 during on-sites field-work. The data collection for buildings and visibile structures was executed using Topcon Hiper V GNSS receiver (accuracy $1 \mathrm{~cm}+1 \mathrm{ppm}$ at horizontal direction); the static survey was performed using the data from the Italian Continuously Operating Reference Stations (CORS) NetGEO and the GNSS measurements were georeferenced in the Italian national geodetic reference system RDN2008-ETRF2000, using the UTM projection. For artefacts scatters areas coordinates data were obtained with the use of Map Plus application for surveying and mapping by mobile phone; data collection techniques via the use of handheld instruments with a good degree of accuracy can facilitate the uniform collection and recording 
When evaluating the current state of archaeological corpus of evidence now available for the Plain of Catania, clear difficulties connected both to the research methods and the quality of the documentation have to be confronted: surveys and excavations were undertaken in different periods, employing varying investigative methodologies with differing objectives ${ }^{19}$. Open and linked archaeological geodata for the area, that is to say computerized geographical data, does not exist ${ }^{20}$ : for the Catania region, only the official restricted areas layer of archaeological sites (Piano Paesaggistico) is accessible, and only through the WMS service for GIS platforms ${ }^{21}$.

Archaeological landscapes carry an impressive amount of data since they consist of many layers made up over centuries, each with specific characteristics and comprising a wide range of archaeological material (pottery, coins, glasses, metals, buildings, residues of conurbations, and so on) from different periods ${ }^{22}$. Digital representation of archaeological data in open formats may play a crucial role not only in cultural heritage preservation, since it offers significant advantages in the dissemination, use, and comprehension of information stored in old reports, archives, collections and museums catalogues, but also in research ${ }^{23}$. This holds particularly true for the data on pottery distribution from survey and excavation projects carried out in Eastern Sicily. However, the majority of legacy data for the research area is available in the form of old maps and paper gazetteers attached to published works. Indeed, useful archaeographic data ${ }^{24}$ is variously dispersed in old reports, papers, conference proceedings and monographs, and unpublished theses. This heterogenous data - mainly consisting of pottery catalogues, drawings and pictures - was harmonised through the creation of a geodatabase, whose main feature is the management of different datasets ${ }^{25}$.

of finds in the field (see Inal et al. 2017). According to González-Tennant (2009), data accuracy can be improved in the field by implementing a workflow that includes handheld devices loaded with a data entry form that restricts users to choosing from specific values; this improves the spatial context of the objects and provenience by attaching precise latitude $(\mathrm{x})$ and longitude $(\mathrm{y})$ coordinates at the time of the find.

19 A total of 385 archaeological sites have been included in the Rural Networks in Sicily Catalogue (Ru.N.S. here- after), recorded over the course of archaeological projects and reconnaissance surveys carried out in the region during the last century; the sites included in the catalogue were assigned to 16 discrete phases of settlement spanning the time range from the Paleolithic $(1100000-8501$ BCE) to the Byzantine periods (537-975 d.C.). The chosen research area (2195 kilometers) encompasses the territories of 21 municipalities, whose archaeological heritage is under the Superintendencies of Catania (central-northern sector), Enna (north-western sector) and Syracuse (southern sector). For a similar project on legacy data for the archaeological landscapes of Enna and Aidone (central Sicily) see Brienza 2018.

20 Geser 2016, 17-28; Handzic, Carlucci 2019.

21 http://www.sitr.regione.sicilia.it/?p=3089.

22 Roberts 1994; Volpe 2007.

23 Bogdani 2009; Bogdani 2019a, 57-88.

24 Anichini, Gattiglia 2012.

25 Brancato et al. 2019a; Brancato et al. 2019b. On geodatabase for archaeology see GonzálezTennant 2009. 

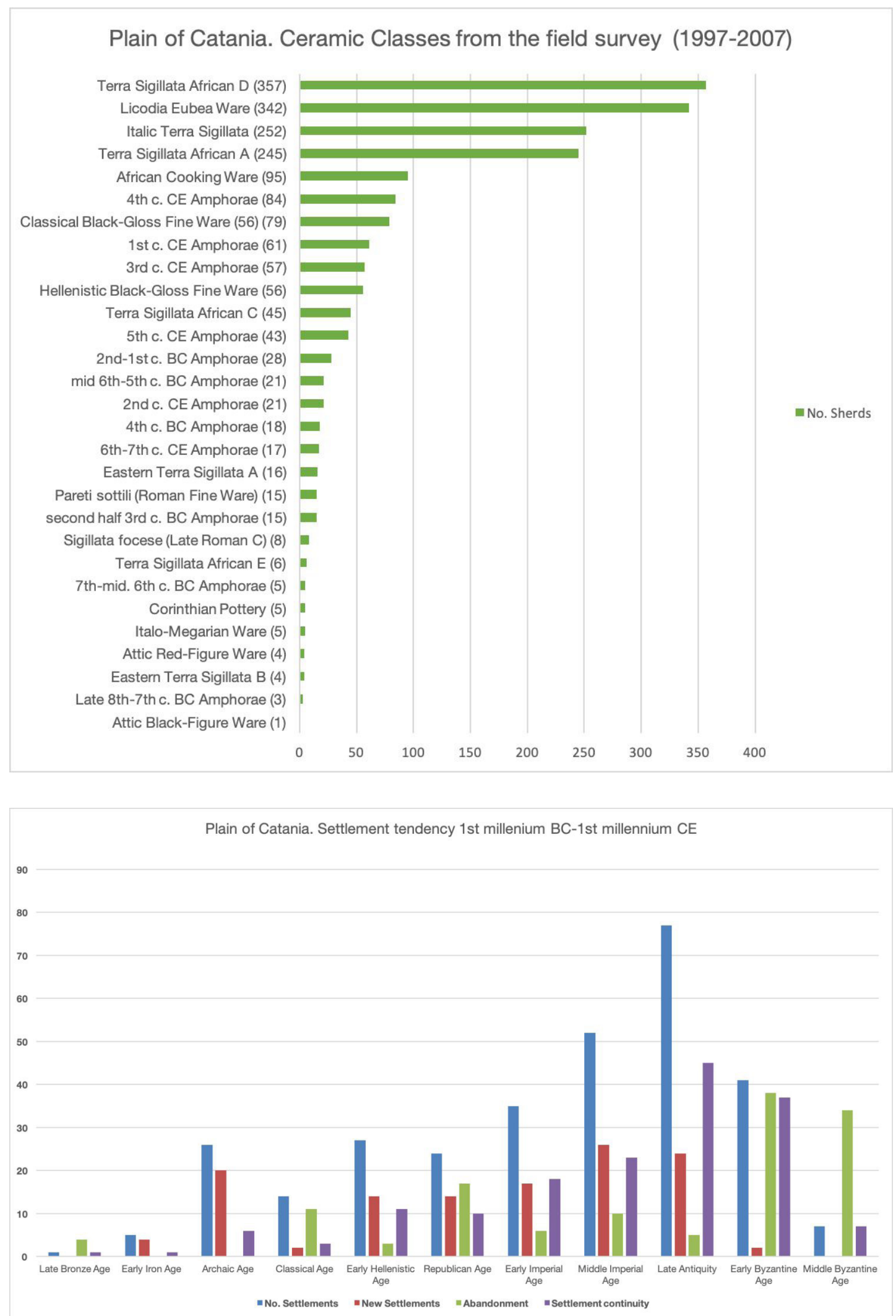

Fig. 6. Sicily, Plain of Catania: A) settlement development from Late Bronze to the Middle Byzantine age; B) number of pottery sherds divided for classes. 
However, even though well-proven tools for organizing and querying information, relational databases do not support global and flexible data-integration mechanisms with other sources, and suffer from limited modelling and reasoning capabilities ${ }^{26}$. In order to take advantage of the rich information collected from the plain of Catania, the relational database was modelled through the OntoCeramic 2.0,4 an OWL 2 ontology: through a taxonomy which refines and extends OntoCeramic $1.0,{ }^{27}$ it models and integrates new field survey and legacy data on pottery distribution. Moreover, the ontology represents the main pottery features such as classes, shape, typology, fabrics, and production chronology ${ }^{28}$. OntoCeramic 2.0 was entirely mapped in the CIDOC Conceptual Reference Model (CRM) ${ }^{29}$, fomal ontology which provide the structure and relationships for Semantic Web data ${ }^{30}$, and have been developed for use in cultural heritage applications generally, and archaeology specifically ${ }^{31}$. Due to its capacity to deal with the archetypal elements of real space and time (i.e. topography and chronology), an ontology is able to compare old and new archaeological data, regardless of the degree of accuracy in its acquisition and publication process ${ }^{32}$.

The final aim of the data digitisation and integration process was to carry out spatial analysis, a useful tool in order understanding settlement pattern dynamics ${ }^{33}$. The importance of Geographic Information Systems (GIS) for spatial analysis is undeniable $^{34}$ : indeed, GIS is not only the ideal medium through which archaeological data can be visualised, but also the best digital environment in which to integrate, map and analyse heterogenous data (viz. databases, archaeographic data, maps, historical and modern cartography, DEM, aerial orthophotos, photogrammetry) ${ }^{35}$. In fine, the archaeological landscape analysis of the Plain of Catania was carried out from a contextual perspective through an integrated GIS modeling approach using

26 Gruber, Tyler 2014.

27 Cantone et al. 2015.

28 Similar projects see La Fragola 2002; Letricot and Szabados 2014.

29 Biagetti 2016.

30 May et al. 2012.

31 Wright 2018.

32 Brancato et al. 2019b, p. 86.

33 Hodder and Orton 1979. On spatial humanities or geo-humanities see Gregory and Geddes 2014; Murrieta-Flores and Martins 2019.

34 Carafa 2013; Verhagen 2018.

35 Bogdani 2009; Bogdani 2019a, 89-122. The processed DEM data used in this work is in decimal degrees and datum WGS84: it is derived from the Global SRTM data at a resolution of 1 arc-second (30 meters) publicated by U.S. Geological Survey USGS Earth Resources Observation and Science EROS Center); it is edited to delineate and flatten water bodies, better define coastlines, remove spikes and wells, and fill small voids; larger areas of missing data or voids were filled by the NGA using interpolation algorithms in conjunction with other sources of elevation data; link: https://ta.cr.usgs.gov/SRTM1Arc. 
computer technology, archaeology, semantic web and topographical analysis ${ }^{36}$. Through the connection of the available body of archaeological knowledge with an indexed collection of ancient texts and mapped places $^{37}$ and with other indexed mapped archeo-databases - where available - it would be possible to elaborate a more accurate comparative settlement system analysis, on the basis of shared and divergent chronological and topographical characteristics.

\section{The Greek age}

The field survey of the western edges of the Catania Plain has highlighted significant settlement exploitation during the Archaic Age. A significant increase compared to the early Iron Age is indicated by the indigenous and Greek production materials found in twenty-six topographic units. The most sizeable occupation was usually identified on lofty positions, above $400 \mathrm{~m}$ a.s.l., naturally defended and strategically located with respect to the road system that crosses the territory, as in the case of Montagna di Ramacca ${ }^{38}$. In the early seventh century BC, the development of a series of medium and small-sized sites located in positions very close - within a few kilometers - of the major indigenous centers is evidenced. One of these sites is Poggio delle Forche (352 $\mathrm{m}$ a.s.l.), located near the Ramacca Mountain ${ }^{39}$ : among the ceramic sherds found on the plateau (UT R79), the majority are Licodia Eubea Ware (56 fragments) ${ }^{40}$ or Greek imports, including Corinthian A transport amphora sherds ${ }^{41}$ (fig. 6a). Similar settlement characteristics are noted for the Archaic occupation of Monte Turcisi (303 m a.s.l,), a steep-walled hill overlooking the Catania Plain from the East, wedged between the valleys of the rivers Dittaino to the north and the Gornalunga to the South. A small phrourion encloses its slightly extended top (1.5 ha): the survey identified a large area of pottery sherds $(200 \mathrm{x}$ $40 \mathrm{~m}$ ) that extends homogeneously along the western slopes of the hill, at varying altitudes: a large amount of ceramics found date from the sixth to the second half of the fifth centuries BC (fig. 7). Today the ascription of the fortification to the Archaic age is under discussion ${ }^{42}$, but the reasons for the settlement on the top of Monte Turcisi in the sixth century are clear ${ }^{43}$ : from the naturally defensible hill top it was possible to control the routes that crossed beneath its slopes, one goeing up the valley of the Margi river from the south and the other up the valley of the

\footnotetext{
36 Gregory et al. 2015.

37 Simon et al. 2015; Barker et al. 2016.

38 Albanese Procelli, Procelli 1982; 1988-89.

39 Adamesteanu 1956, fig. 99.

40 Camera 2018.

41 Albanese Procelli 1996; 1997; Tortorici 2015, pp. 23-26.

42 Jonasch, Winterstein 2016; Jonasch, Winterstein, Ferlito 2019.

43 Procelli 1989, 285-286.
} 

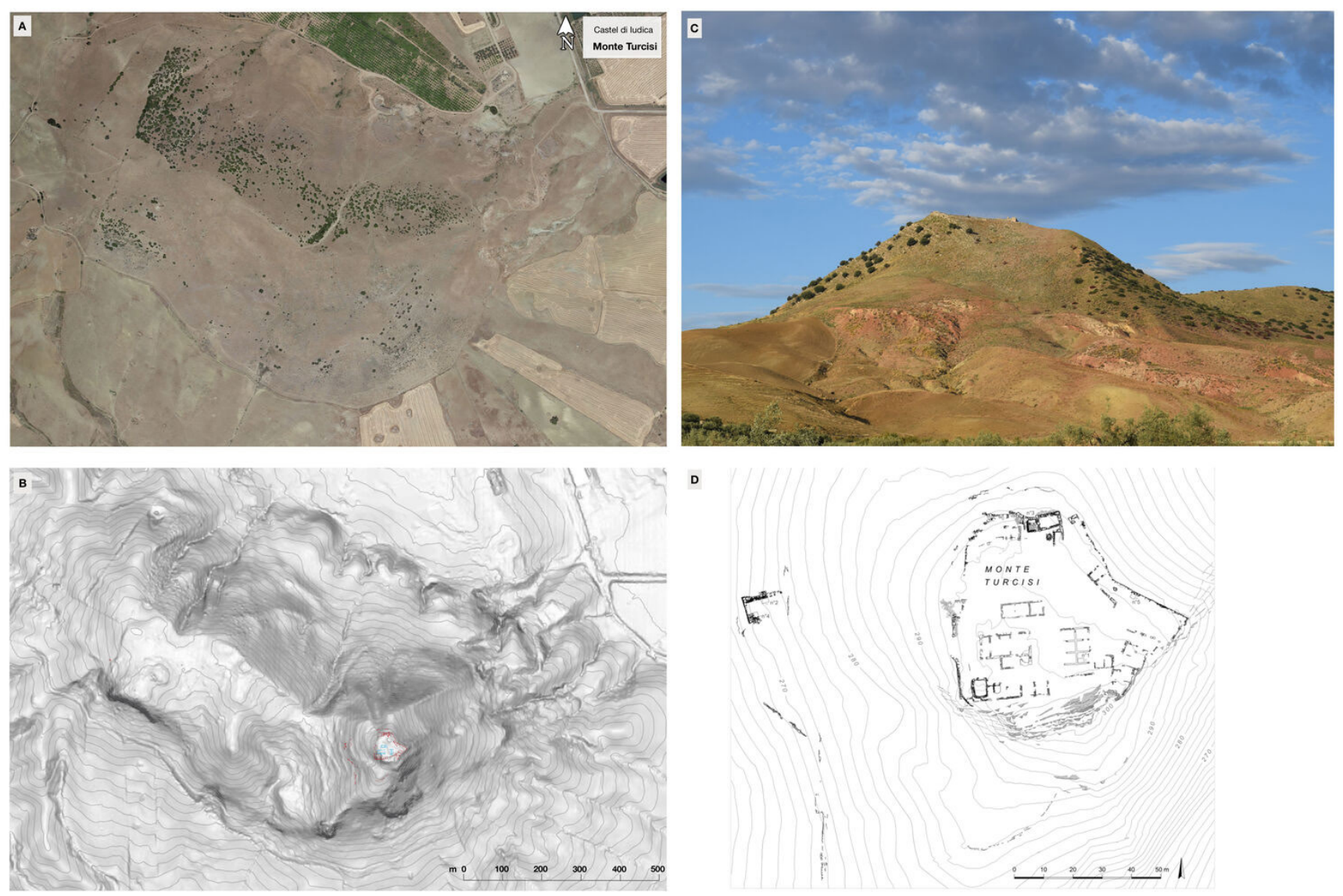

Dittaino river from the east ${ }^{44}$. However, the proximity of Monte Turcisi to the indigenous settlement of Monte Iudica (765 m asl) cannot go unremarked ${ }^{45}$.

The survey data testify not only to the existence of sites located on the heights, but also the development of a different model of land use compared to the Protohistoric age ${ }^{46}$ : the numerous scattered sherd zones identified on the western edges of the Plain of Catania (R97, R80, R61, R67, R102)47 can be interpreted as smallscale rural production centers ${ }^{48}$. It is likely that, as in other region of the island ${ }^{49}$, starting from the end of the seventh to the sixth centuries BC, exploitation of the territory for agro-pastoral purposes began: the planned increase of production may be related to the growing demand for raw materials by the Greeks ${ }^{50}$.

Fig. 7. Sicily, Monte Turcisi (Castel di ludica): A) satellite image of the site

(Google maps 2020); B) the fortress in red (after Jonasch, Winterstein, Ferlito 2019) on the hill's slope analysis carried out on 2 m LIDAR

Composite DTM (ATA 2007-2008, Regione Sicilia); C) view on the hill from North (after Jonasch, Winterstein, Ferlito 2016); plan of the structures on the top (after Jonasch, Winterstein, Ferlito 2019).

44 Procelli 1980, 144.

45 Corretti 1992; Privitera 1988-1989, 85-89; Privitera 1991-92, 26-30.

46 De Angelis 2016, p. 100.

47 Albanese Procelli et al. 2007, 45.

48 Brancato, Caliò 2019.

49 Frasca 2016.

50 Albanese Procelli 2003; De Angelis 2016. 
Compared to the sixth century $\mathrm{BC}$, the evidence decreases substantially in the course of the Classical Age: in fact, the total number of sites dating to the fifth century BC shrinks from twenty-six to thirteen. Numerous sites (11) were not resettled and others (12) there are indications of settlement continuity from the mid-fifth century BC onward only. This picture may be explained in the context of the political instability that characterized the first half of the century, marked by the violent career of Hippocrates of Gela (498/497-490) ${ }^{51}$, and then by the events related to the campaigns of Hieron I of Syracuse (478-466 BC) $)^{52}$ and the Hellenized indigenous leader Ducetius (460-440 BC) $)^{53}$.

These events have certainly to be considered in order to obtain a clear understanding of the rural settlement dynamics on the edges of the territories of Morgantina, Catania and Lentini, poleis deeply involved in these conflicts ${ }^{54}$. The survey highlighted the chronology of the settlement which extended on the top of Poggio delle Forche (UT R125), a small hill south-east of the Ramacca Mountain. The considerable quantity of ceramic artefacts related to daily life, i.e. common ware, household objects (loom weights) and Ionic-Massaliote transport amphorae, may suggest the existence of a stable settlement, active between the Archaic period and the middle of the fifth century BC. By contrast, after a hiatus of information for the second half of the fifth century, the survey data from Monte Turcisi produced numerous ceramics dating from the early fourth to late third centuries $B C$.

In the survey area, ceramic sherds dating to the late fourth-third centuries BC were identified in 27 topographical units: compared to the previous period, there is an impressive increase in the number of settlements (> 90\%) (fig. 6b). However, 11 areas are characterized by chronological markers attesting their use since at least the early fifth century BC. In the Hellenistic age, settlement patterns seem to reach a certain stability. On the other hand, the number of never previously settled areas (14) may be seen as part of the settlement system's evolution, likely involved in the agrarian expansion that took place between the second half of the fourth and the early third centuries $\mathrm{BC}^{55}$. Numerous Hellenistic sites are located in 100 masl positions, usually near springs and water courses. At this time, the most relevant Greek settlements, Montagna di Ramacca and Castel di Iudica, both in decline since since the early fifth century BC - seem to be completely depopulated ${ }^{56}$. Imported material culture from Southern Italy and Greece is recorded in lower surroundings, pointing to the existence of a dispersed rural landscape embedded in the Mediterranean commercial networks. On the basis of archaeological and

51 Herodotus VII, 154, 2-155.

52 Manganaro 1996, 32.

53 Tempio 2014.

54 De Angelis 2016, 101-110.

55 Manganaro 1996; Brancato 2020a.

56 Albanese Procelli, Procelli 1988-89; Privitera 2005. 
technical evidence, new research carried out on the fortification located on Monte Turcisi effectively demonstrated that it was built on its summit in the early fourth century, and used until the end of the third century BC at least ${ }^{57}$ : its role was likely part of a broader strategy to control and protect the rural landscape developed in the Plain of Catania, under the influence of Syracuse, against a possible Carthaginian attack ${ }^{58}$. As highlighted by M. Jonasch, the long walls of the Epipolai in Syracuse, the reconstruction of the city walls from Lentini and Akrai and the foundation of subcolonies, including Adrano in the surrounding area, would offer a suitable setting for the establishment of a military outpost on Monte Turcisi in order to control the access to the Ionian-Etnean area and to ensure the grain production of the Plain of Catania.

\section{The Roman age}

The number of Republican Roman sites reflects the substantial continuity of Hieronian rural settlement and a further expansion dated to the second-early first centuries BC. Compared to the previous phase, the number of total sites increased (24): in 11 topographical units clear traces of continuity are recorded, characterized by the great quantity and quality of the finds, distribution over vast areas and close proximity to river courses and roads. Indeed, some scatter areas can be interpreted as rural occupation-sites, linked to the exploitation of the land: for the first time since Prehistory, settlements are again to be found in the plain, while some of the sites located in impervious positions are definitely abandoned, including the phrourion of Monte Turcisi, part of the rural fortification system of the Hieronian kingdom ${ }^{59}$.

Survey data points to a substantial consolidation of the settlement system between the Late Republican and Early Imperial age (fig. $6 \mathrm{~b})^{60}$. During the first century, the number of sites recorded in the study-area increases from 24 to 35: 18 archaeological sites are characterized by signs of settlement continuity, a marker of the developing strength of landholding during the Republican period. The high number (17) of newly-settled areas is also of great interest: although the framework should be considered with caution due to the lack of stratigraphic data, the settlement pattern dating to the Early Imperial age could be considered as a result of the deduction of Catina as a colony. The increase in the number of rural sites could be related to changes in local landownership brought about by the Augustan

57 A datation to the late fifth century was proposed by R.J.A. Wilson (1987-89, p. 119) and H. Tréziny (1999a-b).

58 Jonasch, Winterstein 2016, Jonasch, Winstein, Ferlito 2019; on rural fortifications see Fachard 2016a-b.

59 Bell 1999.

60 Brancato 2020b. 
distribution of lands to his veterans ${ }^{6}$. Although the area shows no clear signs of centuriation, the Plain of Catania was the only territory available for a wide land redistribution ${ }^{62}$. The same is suggested by the survey data from the Catania Plain, where relevant archaeological areas (likely villae and farms) were first occupied in the Augustan Age, as indicated by the material culture. The settlement continuity of Early Imperial sites (23 on 35 UT) is also accompanied by a significant number of never settled areas (24). The material culture recorded on the surface points to the development of a new form of rural settlement during the Middle Imperial Age: small scatter areas dating to the second century $\mathrm{AD}$ are largely characterized by the presence of tiles, common and coarse ware sherds and the lack of sherds relating to sumptuous goods, occuring in residual percentages where they are recorded. This kind of site is usually located within a buffer area ( $<2$ kilometes) of likely "central places": on the basis of the recorded presence of imports (fine wares and amphora sherds) and even visible structures, these sites could be interpreted as likely landowners' mansions.

During Late antiquity (middle third to fifth century), survey data points to a further increase in the number of identified settlements ${ }^{63}$, which rises from 52 to 77 , an increase of $48 \%$; 45 sites out of 77 show traces of settlement continuity, usually associated with a relevant increase in the sherds' distribution area. New foundations date to the middle of the third century, all usually located at low altitudes: for the first time, a complex settlement system characterized the western edges of the Plain of Catania.

In the middle Dittaino valley, the survey has documented a homogeneous increase in the number of areas of fragments compared to the Early Imperial Age, in particular in relation to the fertile hills of the western sector. In this area, there is the only villa investigated on the edge of the Catania Plain, in the locality of Castellito (Ramacca) (fig. 8a) $)^{64}$. The archaeological site extends on the top of a low knoll (106 $\mathrm{m}$ above sea level) located near the Dittaino river, which flows immediately to the east. The structure of the building is organized around a peristyle from which a series of rooms with mosaic floors is accessible (fig. 8b). Stratigraphy indicated a chronology spanning the third to the end of the sixth centuries $\mathrm{AD}$, and there are numerous signs that indicate the long life of the site $^{65}$. About 2 kilometers northwest of the villa, an area of ceramic sherds (UT R16) was identified at the foot of

61 Tortorici 2016, 289-290.

62 Pfuntner 2019, 165.

63 Gabba 1982-83, 526.

64 Albanese Procelli, Procelli 1988-89, 7-22; Patanè, Buscemi Felici 1998, 200-201, n. 146; see also Wilson 1990, 210.

65 Albanese Procelli, Procelli 1988-89, 21. A new research project focusing Castellito and its surroundings started in 2019, when the restoration of the mosaics started under the direction of Dr. M.T. Magro (Soprintendenza BB.CC.AA. Catania). 

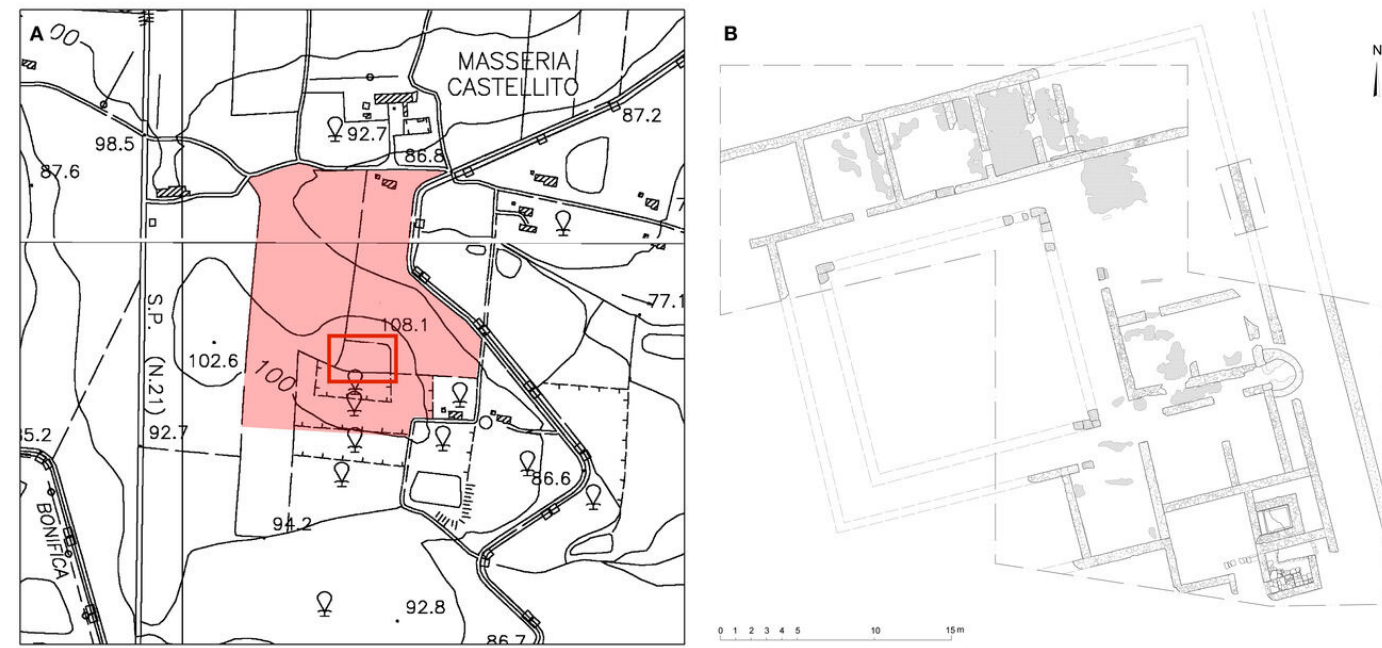

Fig. 8. Sicily, Contrada

Castellito (Ramacca),

the Roman villa,

3rd-5th century CE:

its position in CTR

cartography, s.

633100 (A); plan

of the excavations

(B); the view on the

North-East sector of

the site.

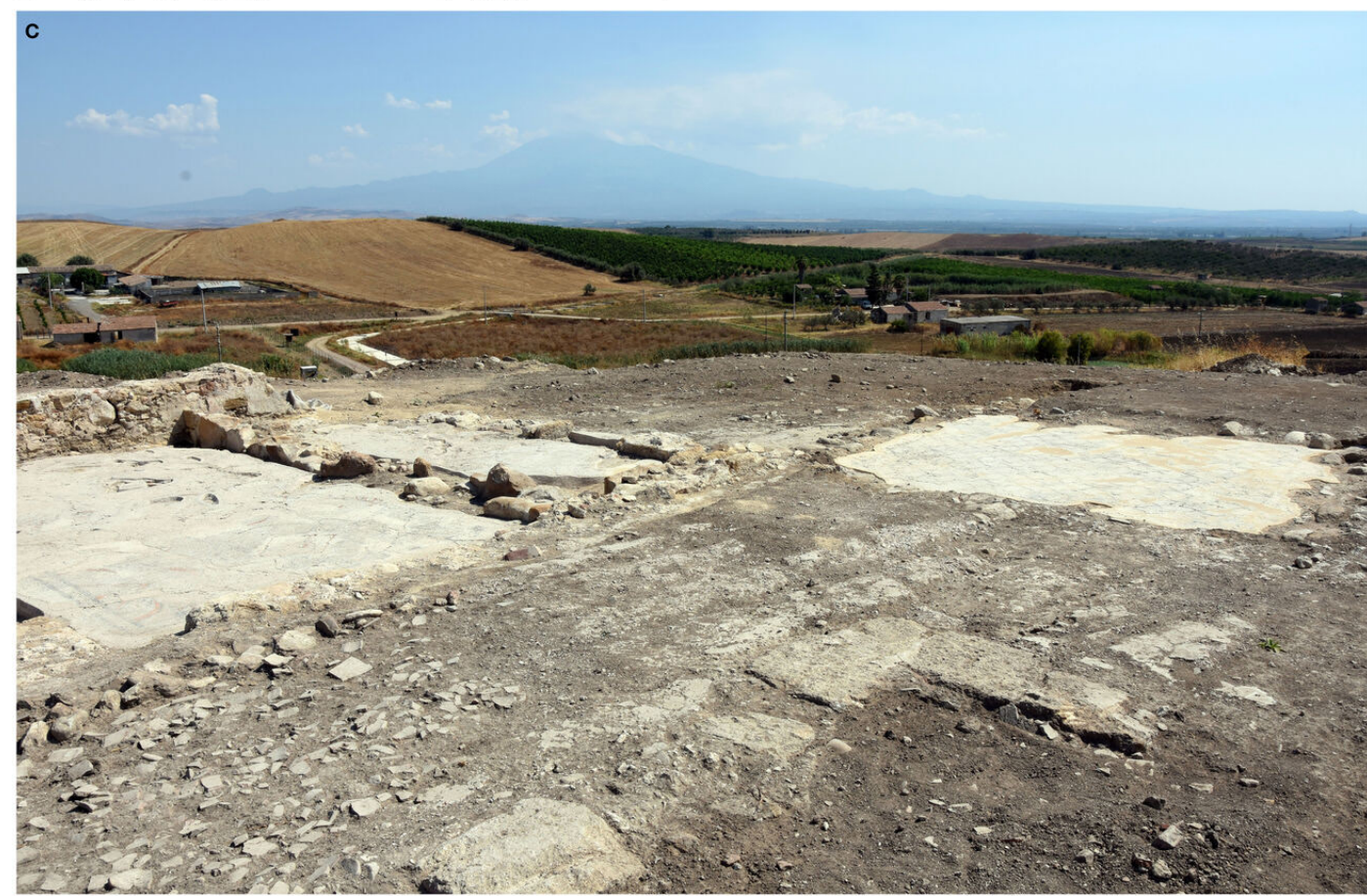

a low knoll: these materials documented a settlement whose life goes from the beginning of the second century $\mathrm{AD}$ until the late seventh century: the presence of a fair amount of ceramics, supported by some fragments of tiles, could indicate the existence of a modest rural settlement, perhaps a production unit directly dependent on the villa (fig. 8c). In the Dittaino River region, the field survey did not identify any area with characteristics that may suggest the existence of other contemporary settlements comparable to the villa of Castellito. E. Procelli and R.M. Albanese have proposed identifying the villa of Castellito with the core of 
the Massa Capitoniana ${ }^{66}$ : in addition to the undoubted proximity of the site to the layout of the Catina Agrigentum road $^{67}$, both the survey data and the topographical analysis that tends to confirm this hypothesis clarify its centrality with respect to the surrounding rural landscape.

The significance of the change which occurred during the Imperial Age in the rural settlement pattern of the Plain of Catania should be considered in the light of the new role of Sicily in the context of the central-western Mediterranean economic system whose fulcrum was the nearby provincia Africa ${ }^{68}$. Indeed, the use of previously unsettled areas of the alluvial plain, whose geomorphological characteristics probably limited agricultural yield, is documented only from the late third century $\mathrm{AD}$. The close topographical relationship between the structure of the rural settlement and the layout of the internal road-system that connected Catania and Agrigento is also evident. Around the middle of the fourth century AD, in order to facilitate the deportatio ad aquam of the cereal production towards the major Sicilian ports, Catania and Agrigento, the centers responsible for the storage of the product - the villae, stationes and vici to be considered linchpins of the rural settlement system - were concentrated along the road. On the basis of the observation of the differences noted between the various forms of settlement attested during the survey, the existence of a composite settlement system can be assumed. These developmental trajectories are understandable if you look at the processes of formation of the large late antiquity estates property, which in Sicily and southern Italy take the specific form of the massa fundorum ${ }^{69}$. The villae were at the top of the hierarchical system that organized the high income of the massae, places where the agricultural product was stored according to the model proposed by D. $\mathrm{Vera}^{70}$. These most significant settlements (villae) persist throughout Late antiquity as cornerstones of the rural productive landscape and gatherers of local agricultural production ${ }^{71}$. These sites, usually located in tight topographical relationship to the main land routes and riverways along the road connecting Catina to Agrigentum, maintained their role into the Early Medieval period ${ }^{72}$.

66 Albanese Procelli, Procelli 1988-89, 22. On Capitoniana, see also Andronico 1983 and Bonacini 2010.

67 It. Ant. 88, 1; 94, 4. For the reconstruction of the road Catina Agrigentum see Uggeri 2004, 251-266; see also Sfacteria 2018; for the first section a Catina Capitoniana see Brancato 2019.

68 Vera 2018; Malfitana and Bonifay 2016.

69 Belvedere 2018.

70 Vera 2018.

71 Belvedere 2018.

72 Castrorao Barba 2014; Arcifa 2017. 


\section{Discussion}

The changes in settlement dynamics that took place in the Plain of Catania from the second half of the eighth century $\mathrm{BC}$ are closely linked to the economic and social structure transformations that occurred in the wider Ionian-Etnean region (fig. 9). Events such as the foundation of the Greek colonies of Catania and Lentini $^{73}$, the expansion of the territorial state of Syracuse ${ }^{74}$ and the long Roman rule (second century BC-middle of the fifth century AD) have clearly affected the settlement organization of the area and connected its economic underpinning to the broader Mediterranean world dynamic ${ }^{75}$. The traditional historiographic narrative describes the Plain of Catania throughout antiquity as capable of producing grain and other agricultural products in quantities well beyond the consumption requi-

Fig. 9. Sicily, Plain of Catania: settlement patterns from the Late Bronze Age to the Late Antiquity.
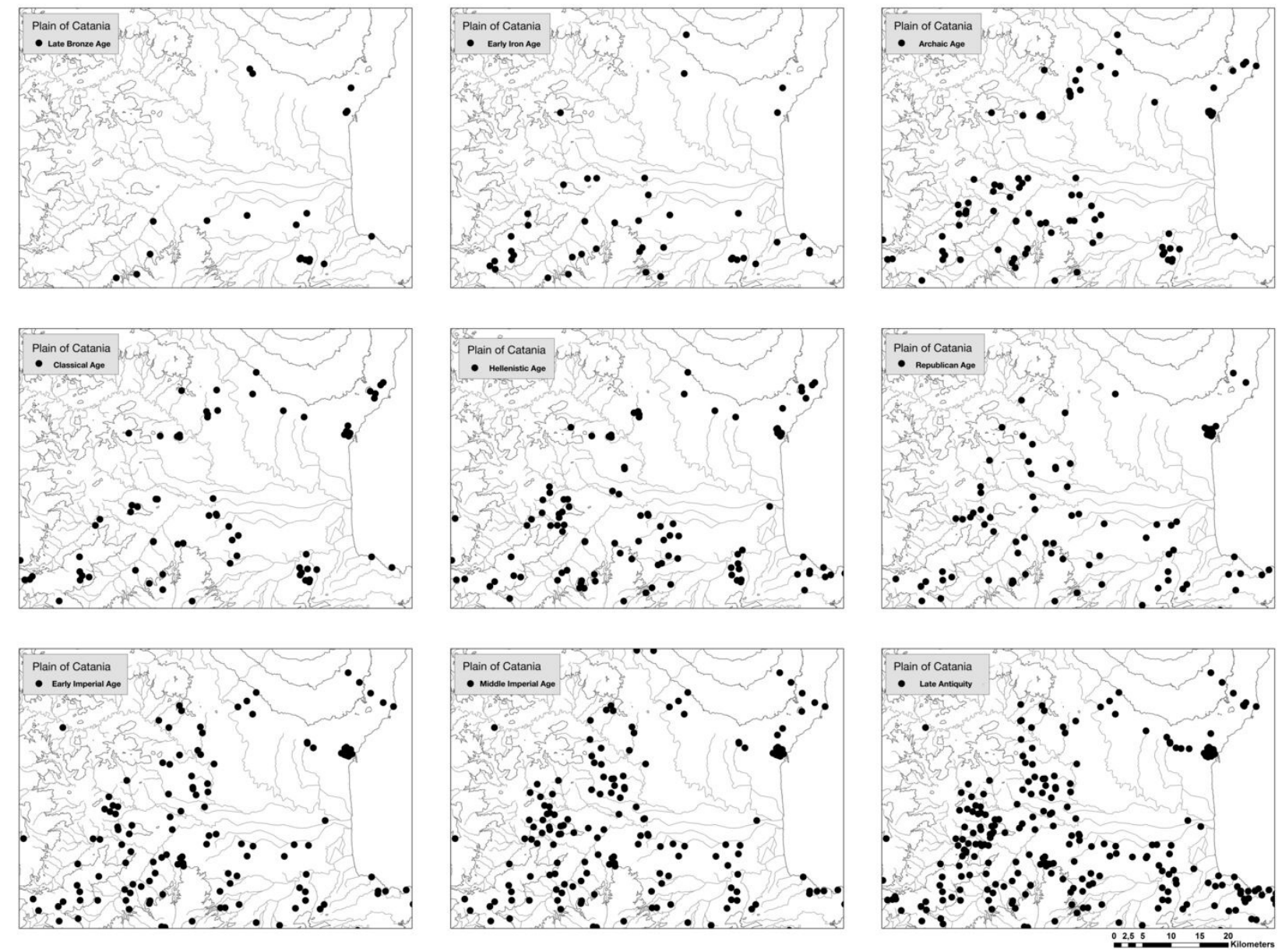

73 De Angelis 2016; Frasca 2017.

74 Bonacasa, Braccesi, De Miro 2002.

75 Wilson 1990; Pfuntner 2019; de Ligt 2019. 
Fig. 10. Sicily, Plain of Catania: marshes in the area of Canale Benante area before the land reclamation works in a historical photo (from Archivio del Consorzio di

Bonifica di Catania) (A), in a geological map (Carta Geologica d'Italia F. 270, Sciuto Patti, 1879-80) (B) and in 2019 (C). rements of its resident population ${ }^{76}$. However, it is likely that the ancient sources have been largely misunderstood due to the erroneous overlap between the territory of Lentini and the plain of Catania in not accurate analysis of ancient sources: in fact, the plain cannot be regarded as an example of a typical fertile floodplain, because until the land reclamation works of the first half of the twentieth century, most of it was characterized by swampy areas and ponds owing to the clayey structure of the soil and the meandering paths of the rivers (fig. 10) ${ }^{77}$. As recently noted, when ancient authors discuss the fertility of the Ionian-Etnean area, they usually refer to the Etna Volcano area and the low hills which surround the wide alluvial plain ${ }^{78}$. Indeed, the hilly lands of Lentini's territory were actually renowned in antiquity for the production of grain ${ }^{79}$ and chose to underline this fact using the barley grain on its coins ${ }^{80}$ : but as written by Aristotle (History of Animals 2, 17) the city also possessed good pasture lands on which animals grew fat, that is probably the vast green and seasonally wet expanses of the alluvial plain. Despite this, there are numerous references to the fertility of the plain, and to its intensive
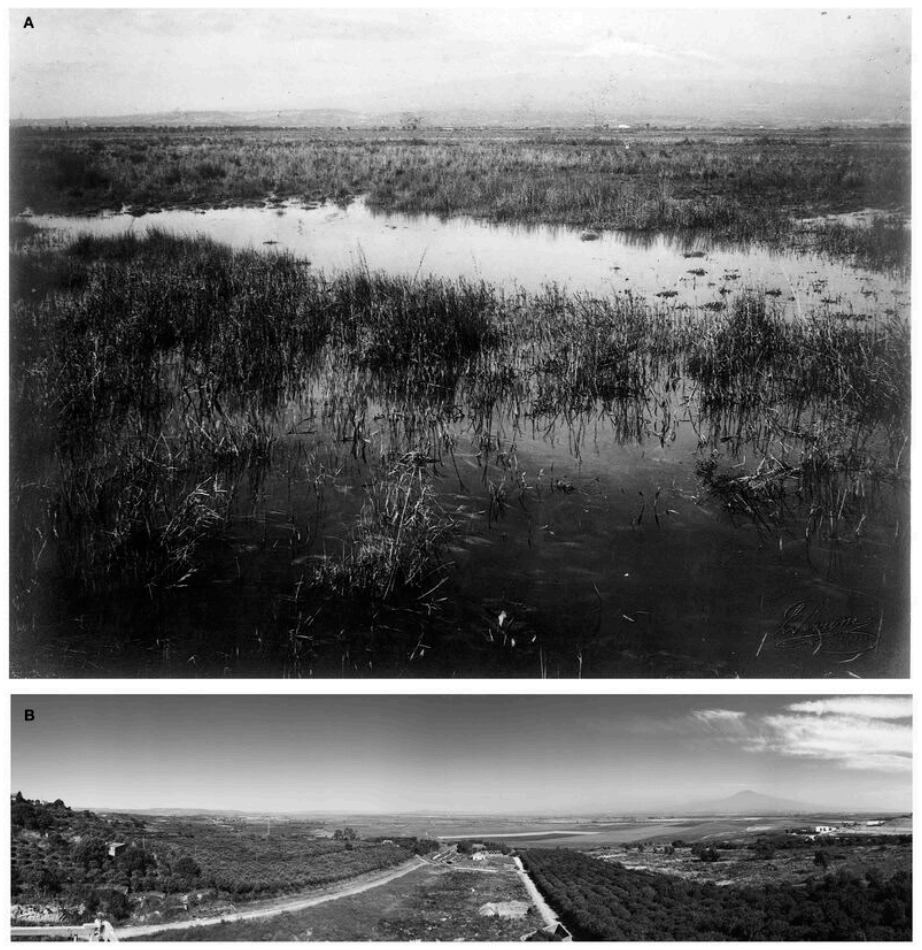

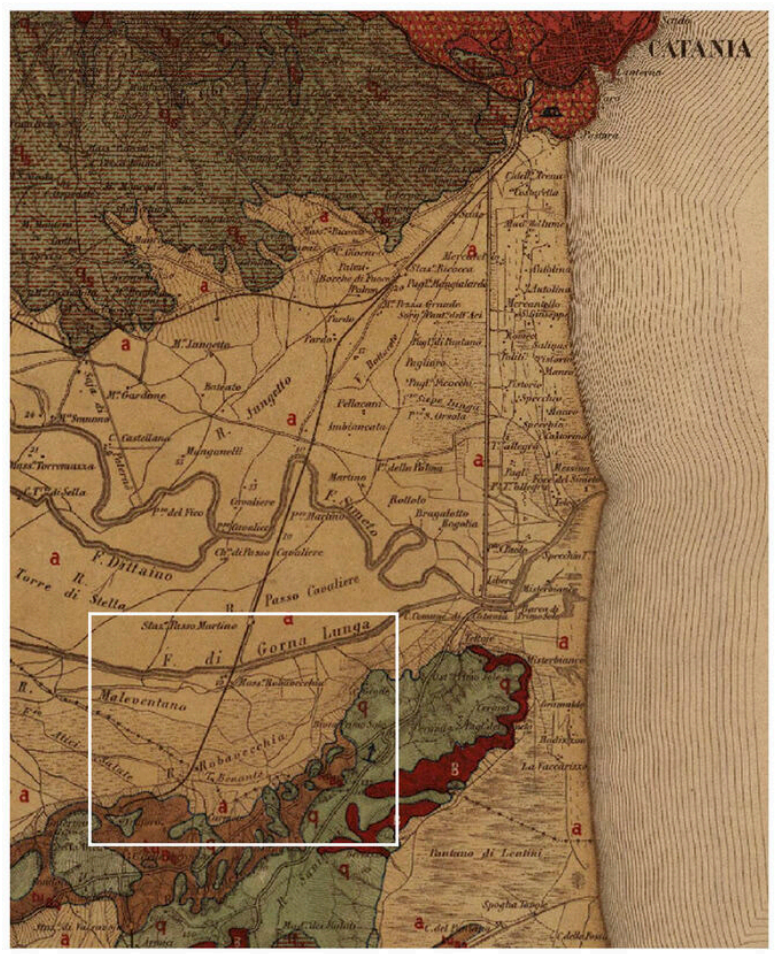

76 Nenci, Vallet 1990, 529-530.

77 Monaco et al. 2004.

78 Considered as the mythical seat of the Laestrygonians (Polib., VIII 9, 13), according to it Diodorus $(5,2,4)$ the wild wheat grew particularly in the Leontinon Pedion, though in other parts of the island as well (Plin., NH III 8, 89); for the other ancient sources on the Leontinoi fields see Freeman 1891, 67; Manni 1981, 89.

79 De Angelis 2000.

80 Lacroix 1965, 109-10. 
and extensive exploitation for agricultural purposes in antiquity: the origin of this myth, tightly linked with that of Sicilia frumentaria, can probably be traced to the agricultural policy of the Syracusan monarch Hieron II (269-215 BCE), when Sicilian agricultural production was, for the first time, comprehensively mobilized through a sophisticated administrative system designed to collect an annual grain tithe from the cities and rural settlements within his kingdom. ${ }^{81}$ Hieron's administrative system was so effective at harnessing the productivity of the island that the Romans retained the annual grain tithe, the decuma, and applied it to the whole of Sicily, as Cicero's "De frumento" (In Verrem II, 3) clearly describes ${ }^{82}$. Between the third and first centuries BC Sicily witnessed an immense political and economic transformation. The role of Sicily in the annona during the Imperial Age has been the subject of a long historiographical dispute, due to the sparsity of data in texts and the well-known importance of the grain production of North Africa and Egypt from the end of the first century $\mathrm{BC}^{83}$. As is well known, classical archaeology is often stigmatized as being text-driven, because the subjects often take their orientation from - and adapts their whole narrative to - the lead given by literary sources ${ }^{84}$.

As a result, the huge cereal production capacity of Greek and Roman Sicily, even organized for wheat monoculture, is a sort of historical and archaeological given ${ }^{85}$ : as well-outlined by F. De Angelis in a famous paper (2006), it is necessary "to move from coarse-grained to fine-grained reconstruction of ancient Sicilian economics [...]. The ancient texts were expressing ideas which sometimes reflect obliquely or not at all what was actually happening on the ground. In addition, extending one or two ancient passages to a long period of time, not to mention the whole of antiquity, is very problematic because it produces a static and one-dimensional picture of the ancient world. This practice has created the notion that the economics of ancient Greek Sicily were solely about agriculture and grain, in large part because the stories have been taken at face value. The written sources need to be combined with more archaeological economic history, in order to get a fuller picture of the past" ${ }^{86}$. In order to understand properly the economics that made possible Greek and Roman Sicily's monumental and cultural achievements, as pointed out by R. Wilson in 1990, the extension of archaeological research beyond the traditional field of "urban" and monumental rural contexts (i.e. villae) was required ${ }^{87}$. Today, for the archaeology of rural landscapes in Sicily it is necessary to consider

\footnotetext{
81 Bell 1999.

82 Whaltall 2011; Prag 2015.

83 Soraci 2011.

84 Snodgrass 2002.

85 Murray 1992, 21; Nenci 1993.

86 De Angelis 2006, 47; see also Morris 2002, 65-67.

87 Feinman 2017, 418-424.
} 
not only new data sources such as zooarchaeology and archaeobotany from the countryside, but also the substantial amount of the aforementioned legacy data. Covering Greek and Roman rural sites (villages, cemeteries, isolated farms, pottery kilns, quarries, etc.), they have passed largely unnoticed and under-appreciated for their potential to contribute to the discussion about the real economic and political significance of Sicily's agricultural resources in the context of the Classic Mediterranean world. Furthermore, a careful and global data analysis allows us to understand that the economic base of Sicily consisted not only of agriculture, but also the exploitation of its numerous natural resources: mineral extraction such as sulfur in the Erei Mountains ${ }^{88}$, limestone quarrying in the Hyblean area ${ }^{89}$, and the timber supply from the woods of Etna $\mathrm{a}^{90}$ stand as examples. It follows that the large and barren areas of the western edges of the Plain of Catania and the mires and meres of its central and south-eastern sectors ${ }^{91}$ should be considered in a contextual analysis of the changes in settlement systems that occurred thoughout the Greek and Roman ages ${ }^{92}$. The alluvial plain was not entirely an ideal place for extensive cereal agriculture, but even so large parts of it were likely embedded in the economic system through the exploitation of uncultivated areas in other ways: pastoralism in the semi-arid hilly environments and breeding, fishing and salt production in wetlands, for example. However, there are few archaeological indicators useful for clarifying the contribution of other such production activities to the the basis of the local economy ${ }^{93}$ : pastoralism, breeding and the exploitation of uncultivated lands were activities conducted in natural environments whose extreme characteristics have been mitigated through a series of land reclamation works in the first half of twentieth century, as the example of the swampy south-eastern sector of the Catania Plain may clearly demonstrate ${ }^{94}$. Indeed, even if it is an assumption, the abundance of water in the area likely favoured the development of animalbreeding from the early stages of Prehistory ${ }^{95}$. More directly, the discovery in the desolate territory of Ramacca of the marble epitaph of Abdalas ${ }^{96}$ - magister Ovium of Domitia Longina $a^{97}$ is a good archaeological indicator for the importance of herding in the context of a great imperial estate (saltus), which extended in the interior through the vast and desolate hills towards Enna ${ }^{98}$.

\footnotetext{
88 Zambito 2014.

89 Felici, Buscemi Felici 2004.

90 Molè 2008, 37; Tortorici 2016, 267.

91 Brancato, Manganelli 2017.

92 Fantasia 1999; Traina 1986.

93 Volpe 2016.

94 Monaco et al. 2000, 118.

95 Maniscalco 2009.

96 http://sicily.classics.ox.ac.uk/inscription/ISic0628.

97 Salmeri 1984.

98 For the economic integration of Roman Italy, see de Haas, Tol 2017.
} 
Demonstrably, in data analysis of Greek and Roman rural settlement it is necessary to go beyond stereotypes related to an agrarian production dedicated to monoculture: throughout antiquity, the pairing of agricultural activities with exploitation of uncultivated lands should be an expected part of everyday life. Though we can't reconstruct with certainty a single estate's boundaries before the Medieval period ${ }^{99}$, for a long time, the rural economy of ancient Sicily was often treated as the same as the villa economy - which is a nonsense for the province as a whole - and even within the villa economy, the concentration was almost exclusively on arable and pastoral farming, not on any other means of exploiting the land ${ }^{100}$. Nevertheless, as we know from historical sources, certainly exploitation of uncultivated lands was a structural feature of the European economy in the transition from Late Antiquity to the Middle Ages (the sixth to tenth centuries) ${ }^{10}$.

\section{Conclusions}

It must be emphasised, therefore, that the reconstruction of land-use is a problem we particularly have to grapple with in order to understand the evolution of the rural landscape in Greek and Roman Sicily: in order to grasp the relations between settlement patterns and economy ${ }^{102}$, a global approach is required also for data management ${ }^{103}$. Indeed, archaeological landscapes contain an impressive amount of complexity because different levels of preservation and loss of individual features through time have resulted in any given landscape comprising a wide range of fragmented features dating from different periods ${ }^{104}$ : T.J. Wilkinson admits even that there is little chance of achieving any form of total landscape archaeology ${ }^{105}$. In this light, the legacy data available for Sicily is of fundamental importance for the archaeology of rural landscapes: indeed, it is clearly necessary to connect our dataset to as broad as possible an amount of archaeological, topographical, historical, numismatical, epigraphical and archaeobotanical data, sufficient to understand settlement dynamics on a regional scale ${ }^{106}$. As the case of the digital corpus of stone inscriptions I.Sicily led by J. Prag clearly demonstrates ${ }^{107}$, only the systematic process of digitizating legacy data, linking it to archaeological resources available

99 Erdkamp, Verboven and Zuiderhoek 2015; for Early Medieval Sicily, see Arcifa 2017.

100 Traina 1985; Hingley and Miles 2002, 158-171; Launaro 2015; Marzano 2015; for Sicily, see Sfameni 2018.

101 Montanari 1987; Bresc 2001.

102 Feinman 2017.

103 Volpe 2007; Attema 2017, 433-436.

104 Roberts 1994, 33-36.

105 Wilkinson 2003, 7.

106 For example, see Bogdani 2019b.

107 Prag and Chartrand 2018. 
on the Web will allow scholars to begin a proper contextual spatial analysis of settlement patterns and economy of Greek and Roman Sicily ${ }^{108}$. Therefore, the OntoCeramic 2.0 project may be a first step towards the definition of an ontology for the complex reality of archaeological landscapes of ancient Sicily, the artificial and natural processes that shaped them, and island's social, cultural, and economic changes. Semantic Web and ontologies can help archaeologists in combining datasets, but the creation of linked and open data structures available for ancient Sicily is required, in order to bring archaeological resources together and make them interoperable ${ }^{109}$ : this may allow in future functionality such as federated cross-search across different datasets, and the mapping of heterogeneous data to scholars, independent researchers and authoritative structures ${ }^{10}$ to build a broader data source platform.

\section{Bibliography}

Adamesteanu, Dinu. 1956. "Le fortificazioni ad aggere della Sicilia centro-orientale". Rendiconti della Classe di Scienze morali, storiche e Filologiche dell'Accademia dei Lincei s. 8, 11: 358-372.

Albanese Procelli, Rosa M. 1996. "Appunti sulla distribuzione delle anfore commerciali nella Sicilia arcaica". Kokalos 62: 91-137.

—. 1997. "Èchanges dans la Sicile archaïque: Amphores commeniales, intermédiaires redistribution en milieu indigène". Revue Archéologique 1: 3-25.

2003. Siculi, Sicani, Elimi. Forme di identità, modi di contatto e processi di trasformazione. Milano: Longanesi.

Albanese Procelli, Rosa M. and Enrico Procelli. 1982. "Ramacca (Catania). Campagne di scavo degli anni 1978, 1981 e 1982". Notizie degli scavi di antichità s. 1: pp-pp.

. 1988-1989. "Ramacca (Catania). Saggi di scavo nelle contrade Castellito e Montagna negli anni 1978, 1981 e 1982". Notizie degli scavi di antichità s. 8, 4243: 7-148.

Albanese Procelli, Rosa M., Francesca Alberghina, Maria Brancato, Enrico Procelli, and Giuseppina Sirena. 2007. "The Project and the First Results of the Gornalunga and Margi Valley Survey". In Uplands in Ancient Sicily and Calabria, edited by Matthew Fitzjohn, 35-48. London: Accordia Research Centre: University of London.

Alcock, Susan. E. 1993. Graecia Capta: The Landscapes of Roman Greece. Cambridge: Cambridge University Press.

Allison, Penelope. 2008. "Dealing with Legacy Data - an introduction". Internet Archaeology 24. https://doi.org/10.11141/ia.24.8.

108 Gattiglia 2015.

109 Geser and Guntram 2016; Wright 2018; Wright and Richards 2018; Bogdani 2019a.

110 Barker et al. 2016; Gualandi et al. 2016; Richards and Niccolucci 2019a-b; Wright and Gattiglia 2018. 
Andronico, Elisa. 1983. "La mansio di Capitoniana sulla via Catina Agrigentum. Una propo- sta di identificazione”. Klearchos 25: 5-25.

Arcifa, Lucia. 2001. "Dinamiche insediative nel territorio di Mineo tra tardoantico e bassomedioevo. Il castrum di Monte Catalfaro". Mélanges de l'École française de Rome - Moyen Âge 113: 269-311.

. 2017. "Dinamiche insediative e grande proprietà nella Sicilia bizantina. Uno sguardo archeologico". In L'héritage byzantin en Italie (VIIIe-XIIe siècle). IV. Habitat et structure agraire (Roma 17-18 dicembre 2010) edited by Jean-Marie Martin, Annick Peter-Custot and Vivien Prigent, 237-67. Rome: Collection de 1'Ecole Française de Rome 531.

Attema, Peter. 2017. "Landscape Archaeology in Italy: Past Questions, Current State and Future Directions" In: The Economic Integration of Roman Italy, edited by Tymon C.A. de Haas and Gijs Tol, 426-436. Leiden, Boston: Brill.

Ayala, Gianna. and Charly French. 2003. "Holocene landscape dynamics in a Sicilian upland river valley". In: Alluvial Archaeology in Europe, edited by Andi J. Howard, Mark G. Macklin and David G. Passmore, 229-35. Lisse: Sweets \& Zeitlinger.

2005 "Erosion modeling of past land-use practices in the Fiume di Sotto di Troina river valley, north-central Sicily". Geoarchaeolgy 20 (2): 149-68.

Barker, Elton, Rainer Simon, Leif Isaksen and L., Pau de Soto Cañamares. 2016. "The Pleiades Gazetteer and the Pelagios Project". In: Placing Names: Enriching and Integrating Gazetteers, edited by Merrick Lex Berman, Ruth Mostern, and Humphrey Southall, 97-109. Bloomington: Indiana University Press.

Bejor, Giorgio. 1983. "Gli insediamenti della Sicilia romana: distribuzione, tipologie e sviluppo da un primo inventario dei dati archeologici”. In: Società romana e impero tardo-antico. Le merci, gli insediamenti III, edited by Andrea Giardina, 463-519. Roma-Bari: Laterza.

Bell, Malcom. 1999. "Centro e periferia nel regno siracusano di Ierone II". In: La colonisation grecque en Méditerranée occidentale. Actes de la rencontre scientifique en hommage à Georges Vallet organisée par le Centre Jean-Bérard, l'École française de Rome, l'Istituto universitario orientale et l'Università degli studi di Napoli «Federico II» (Rome-Naples, 15-18 novembre 1995) Rome: École Française de Rome, 1999, edited by Pierre Lévêque, 257-277. Paris: Publications de l'École française de Rome, 251.

Belvedere, Oscar. 2018. "Massa fundorum, si può individuare sul terreno?". In Römisches Sizilien: Stadt und Land zwischen Monumentalisierung und Ökonomie, Krise und Entwicklung / La Sicilia Romana: Città e Territorio tra monumentalizzazione ed economia, crisi e sviluppo edited by Oscar Belvedere and Johannes Bergemann, 129-42. Palermo: Palermo University Press.

Belvedere, Oscar and Johannes Bergemann, eds. 2018. Römisches Sizilien: Stadt und Land zwischen Monumentalisierung und Ökonomie, Krise und Entwicklung / La Sicilia Romana: Città e Territorio tra monumentalizzazione ed economia, crisi e sviluppo. Palermo: Palermo University Press.

Biagetti, Maria T. 2016. "An ontological model for the integration of cultural heritage information: CIDOC-CRM”. JLIS 7(3): 43-77. DOI: http://dx.doi.org/10.4403/jlis. it-11930. 
Bintliff, John. 1997. "Regional Survey, Demography, and the Rise of Complex Societies in the Ancient Aegean: Core-Periphery, Neo-Malthusian, and Other Interpretive Models." Journal of Field Archaeology 24 (1): 1-38.

Biondi, Giacomo. 2002. "Per una carta archeologica del territorio di Centuripe". In: Scavi e ricerche a Centuripe, edited by Giovanni Rizza, 41-81. Catania: Edizioni CNR.

Bogdani, Julian. 2009. “Gestione dei dati per l'archeologia. GIS per l'archeologia”. In: Groma 2. In profondità senza scavare. Metodologie di indagine non invasiva e diagnostica per l'archeologia, edited by Enrico Giorgi, 421-438. Bologna: BraDypUS.

2019a. Archeologia e tecnologie di rete: metodi strumenti e risorse digitali. I Cardini di Groma 4. Roma: Bradypus.

2019b. "Linking coptic literary manuscripts to the archaeological context by means of Digital Humanities : the case of 'PAThs' project 2018". Adamantius 24: 200-210.

Bonacasa, Nicola, Lorenzo Braccesi and Ernesto De Miro, eds. 2002. La Sicilia dei due Dionisî, Atti della settimana di studio Agrigento 24-28 febbraio 1999. Roma: L'Erma di Bretschneider.

Bonacini, Elisa. 2007. Il territorio calatino nella Sicilia imperiale e tardoromana. Oxford: British Archaeological Reports.

. 2010. "Una proposta di identificazione lungo la via a Catina Agrigentum". Aitna 4: 79-92.

Bonnier, Anton, Martin Finné and Erika Weiberg. 2019. "Examining Land-Use through GIS-Based Kernel Density Estimation: A Re-Evaluation of Legacy Data from the Berbati-Limnes Survey". Journal of Field Archaeology 44(2): 70-83. DOI: 10.1080/00934690.2019.1570481.

Brancato, Rodolfo. 2018. "Profilo topografico dei paesaggi rurali della Piana di Catania". PhD diss., University of Catania.

2019. "Nuovi dati sui paesaggi rurali nella Piana di Catania: insediamento e viabilità tra età ellenistica ed età imperiale". Journal of Ancient Topography 27: 309-340.

_ 2020a. "Paesaggio rurale ed economia in età ellenistica nel territorio di Catania (Sicilia orientale)". Thiasos 9 (1): 45-75.

. 2020b. "Il Territorio di Catina in età imperiale: paesaggio rurale ed economia nella Sicilia romana". Atlante Tematico di Topografia Antica 29: 269-290.

Brancato, Rodolfo and Laura Manganelli. 2017. "Contributo alla carta archeologica del territorio tra Catania e Lentini (IGM 270 III SO, Reitano)". Journal of Ancient Topography 27: 87-108.

Brancato, Rodolfo and Luigi Maria Caliò. 2019. "Paesaggio fortificato e insediamento rurale nella Sicilia arcaica (metà VII - metà V secolo a.C.). Nuovi dati dai margini della Piana di Catania". Atlante Tematico di Topografia Antica 29: 133-54.

Brancato Rodolfo, Marianna Nicolosi-Asmundo, Grazia Pagano, Daniele Francesco Santamaria and Salvatore Ucchino. 2019a. "Towards an ontology for investigating on archaeological Sicilian landscapes". In: ODOCH 2019 Open Data and Ontolo- 
gies for Cultural Heritage Proceedings of the First International Workshop on Open Data and Ontologies for Cultural Heritage co-located with the 31st International Conference on Advanced Information Systems Engineering (CAiSE 2019) Rome, Italy, June 3, edited by Antonella Poggi, 85-90. Vol-2375 urn:nbn:de:0074-2375-4. (http://ceur-ws.org/Vol-2375/).

Brancato Rodolfo, Marianna Nicolosi-Asmundo, Grazia Pagano, Daniele Francesco Santamaria and Salvatore Ucchino. 2019b. "An Ontology for Legacy Data on Ancient Ceramics of the Plain of Catania". In: CILC 2019 Italian Conference on Computational Logic Proceedings of the $34^{\text {th }}$ Italian Conference on Computational Logic Trieste, Italy, June 19-21, 2019, edited by Alberto Casagrande and Eugenio Omodeo, 59-67. Trieste (http://ceur-ws.org/Vol-2396/paper28.pdf).

Bresc, Henri. 2001, Mulini ad acqua in Sicilia: $i$ mulini, i paratori, le cartiere e altre applicazioni. Palermo: L'Epos.

Brienza, Emanuele. 2018. "Un approccio per l'archeologia dei paesaggi nel territorio di Enna e Morgantina”. Cronache di archeologia 37: 207-230.

Burgio, Aurelio. 2013. "Dinamiche insediative nel comprensorio di Cignana. Continuità e discontinuità tra l'età imperiale e l'età bizantina". Sicilia Antiqua 10: 31-53.

2017. "Archaeological survey projects in Sicily: issues and best practices from Eighties to present time". In: Survey-Archäologie Naturwissenschaftlich-technische und historische Methode in Italien und Deutschland, edited by Johannes Bergemann and Oscar Belvedere, 101-111. Göttingen: Verlag Marie Leidorf.

Camera, Marco. 2018. La ceramica di Licodia Eubea. Roma: Quasar 2018.

Cappers René T.J. and Daam C.M. Raemaekers. 2008. "Cereal cultivation at Swifterbant? Neolithic Wetland Farming on the North European Plain". Current Anthropo$\log y$ 49(3): 385-402.

Carbone S., Branca S., Lentini F., eds. 2009. Note illustrative della Carta geologica d'Italia alla scala 1:50.000. Foglio 634 Catania. Firenze: ISPRA Servizio Geologico d'Italia, Organo Cartografico dello Stato, S.EL.CA. s.r.l.

Carafa, Paolo. 2013. "Teaching and Researching with the GIS: an archaeological story”. J-Reading 1: 73-83. (DOI: 10.4458/0900-08).

Castrorao Barba, Angelo. 2014. "Le ville romane in Italia tra III e VI sec. d C.: approccio statistico e considerazioni generali". Amoenitas 3: 9-24

Concannon, Cavan and Lindsey Mazurek, eds. 2016. Across the Corrupting Sea: PostBraudelian Approaches to the Ancient Eastern Mediterranean. London: Routledge.

Corretti, Alessandro. 1992. "Monte ludica". In: Bibliografia topografica della colonizzazione greca in Italia e nelle isole tirreniche 10, edited by Giuseppe Nenci and Georges Vallet, 377-380. Pisa: Scuola normale superiore; Roma: Ecole française de Rome.

De Angelis, Franco. 2000. "Estimating the Agricultural Base of Greek". Papers of the British School at Rome, 68: 111-148.

. 2006. "Going against the Grain in Sicilian Greek Economics". Greece \& Rome 53, no. 1 (Apr., 2006): 29-47. 
2016. Archaic and Classical Sicily. A social and economic history. New York: Oxford University Press.

De Felice, Giuliano, Maria Giuseppina Sibilano and Giuliano Volpe. 2008. "Ripensare la documentazione archeologica: nuovi percorsi per la ricerca e la comunicazione". Archeologia e Calcolatori 19: 271-291.

de Haas, Tymon C.A., and Gijs, Tol, eds. 2017. The Economic Integration of Roman Italy. Leiden, Boston: Brill.

de Ligt, Luuk. 2019. "The Impact of Roman Rule on the Urban System of Sicily". In: Regional Urban Systems in the Roman World, 150 BCE - 250 CE, edited by Luuk de Ligt and John Bintliff. Mnemosyne, Supplements 431. Brill: Leiden-Boston.

Dunbabin, Thomas J. 1948. The Western Greeks. Oxford: Clarendon Press.

Erdkamp Paul, Verboven Koenraad and Zuiderhoek Arjan, eds, 2015. Ownership and Exploitation of Land and Natural Resources in the Roman World. Oxford: Oxford University Press.

Fachard, Sylvian. 2016a. Studying Rural Fortifications. In: New Research on Fortifications in the Ancient Mediterranean and the Near East I, edited by Rune Frederiksen, Silke Müth, Peter I. Schneider and Mike Schnelle, 207-230. Oxford; Philadelphia: Oxbow Books.

. 2016b. Studying Rural Fortifications: A Landscape Approach. In: New Research on Fortifications in the Ancient Mediterranean and the Near East II, edited by Rune Frederiksen, Silke Müth, Peter I. Schneider and Mike Schnelle, 413-416. Oxford; Philadelphia: Oxbow Books.

Fantasia, Fantasia. 1999. "Aree marginali nella Grecia antica: paludi e bonifiche". In: Demografia, sistemi agrari, regimi alimentari nel mondo antico. Atti del Convegno Internazionale di Studi (Parma 17-19 ottobre 1997), edited by Domenico Vera, 65116. Bari: Edipuglia.

Farinetti, Emeri. 2011. "Boeotian landscapes. A GIS-based study for the reconstruction and interpretation of the archaeological datasets of ancient Boeotia". BAR 2195. Oxford: Archaeopress

Feinman, Gary M. 2017. "Roman Economic Practice across Time and Space: An Outside Perspective". In: The Economic Integration of Roman Italy, edited by Tymon C.A. de Haas and Gijs Tol, 417-425. Leiden, Boston: Brill.

Felici, Enrico. 2016. Nos flumina arcemus, derigimus, avertimus. Canali, lagune, spiagge e porti nel Mediterraneo antico. Bari: Edipuglia.

Felici, Enrico and Graziella Buscemi Felici. 2004. "Cave costiere nel territorio di Lentini”. In: Leontinoi, il mare, il fiume, la città (Atti della giornata di studio. Lentini 4 maggio 2002), edited by Massimo Frasca, 27-50. Siracusa: Maimone.

Frasca, Massimo. 2009. Leontinoi. Roma: Giorgio Bretschneider editore.

. 2016. Archeologia degli Iblei. Indigeni e Greci nell'altipiano ibleo tra la prima e la seconda Età del Ferro. Lagonegro: Ediz. Storia e Studi Sociali.

2017. Città dei Greci in Sicilia. Dalla fondazione alla conquista romana. Lagonegro: Ediz. Storia e Studi Sociali. 
Freeman, Edward August. 1891. The History of Sicily from the Earliest Times 2 voll. Oxford: Clarendon Press.

Gabba, Emilio. 1982-1983. “La Sicilia nel III-IV sec. d.C.”. Kokalos 28-29: 516-529.

Gattiglia, Gabriele. 2015. "Think big about data: Archaeology and the Big Data challenge”. Archäologische Informationen 38: 113-124.

Geser, Guntram. 2016. ARIADNE WP15 Study: Towards a Web of Archaeological Linked Open Data. Salzburg: Ariadne.

Giannitrapani, Enrico. 2017. "Paesaggi e dinamiche del popolamento di età preistorica nella Sicilia centrale". in Mappa Data Book 2, edited by Francesca Anichini and Maria Letizia Gualandi, 43-64. Roma: Edizioni Nuova Cultura.

González-Tennant, Edward. 2009. "Using Geodatabases to Generate Living Documents for Archaeology: A Case Study from the Otago Goldfields, New Zealand". Historical Archaeology: 20-37.

Gregory, Ian N., Alistair, Geddes (eds), 2014. Toward Spatial Humanities: Historical GIS and Spatial History (The Spatial Humanities). Bloomington: Indiana University Press.

Gregory, Ian N., Christopher Donaldson, Patricia Murrieta-Flores and Paul Rayson. 2015. "Geoparsing, GIS, and textual analysis: current developments in spatial humanities research". International Journal of Humanities and Arts Computing 9 (1), 1-14. doi:10.3366/ijhac.2015.0135.

Gruber, Ethan and Tyler Jo Smith. 2014. "Linked open Greek pottery". In: Computer Applications in Archaeology. https://caa2014.sciencesconf.org/46119/document

Gualandi, Maria L., Roberto Scopigno, Lior Wolf, Julian Richards, Jaume GarrigosBuxeda, Michael Heinzelmann, Miguel Angel Hervas, Massimo Zallocco. 2016. "ArchAIDE-Archaeological Automatic Interpretation and Documentation of cEramics". In: Eurographics. Workshop on Graphics and Cultural Heritage. The Eurographics Association. Doi:10.2312/gch.201614083.

Hawthorne, John. 1996. Commensalism and common sense: a new approach to archaeological ceramics. Assemblage 1. https://archaeologydataservice.ac.uk/archives/view/assemblage/html/1/hawth.html

Handzic, Meliha and Daniela Carlucci, eds. 2019. Knowledge Management, Arts, and Humanities: Interdisciplinary Approaches and the Benefits of Collaboration. Cham: Springer.

Hingley, Richard and David Miles. 2002. "The human impact on the landscape". In: The Roman Era: The British Isles 55 BC-AD 410, edited by Peter Salway, 141-171. Oxford, New York; Oxford University Press.

Hodder, Ian and Clive Orton. 1979. Spatial Analysis in Archaeology. New York / London: Cambridge University Press.

Holm, Adolf. 1896-1906. Storia della Sicilia nell'antichità I- III. Turin: C. Clausen.

Jonasch, Melanie and Claudia Winterstein. 2016. "Monte Turcisi, Italien Ein griechischer Militärstützpunkt in Ostsizilien". In: e-Forschungsberichte 2016 Des Deutschen ArchäOlogischen Instituts eDAI-F 3: 87-102. 
Jonasch, Melanie, Claudia Winterstein and Flavio Ferlito. 2019. "Nuove ricerche sulla fortezza greca di Monte Turcisi (CT) - Rapporto preliminare". In FOLDER 446: $1-24$.

Inal, Cevat, Kocak, Omur Esen, Sercan Bulbul and Rahim Kizgut. 2017. "Surveying And Mapping Using Mobile Phone in Archaeological Settlements". Geographia Technica 12 (2): 82-96. Doi: 10.21163/Gt_2017.122.08.

Lacroix, Leon. 1965. Monnaies et colonisation dans l'occident grec. Brussels: Académie Royale de Belgique.

Lanteri, Rosa. 1997. Augusta e il suo territorio: elementi per una carta archeologica. Catania: Maimone.

Launaro, Alessandro. 2015. "The Nature of the Villa Economy". In: Ownership and Exploitation of Land and Natural Resources in the Roman World, edited by Paul Erdkamp, Koenraad Verboven, Arjan Zuiderhoek, 173-186, Oxford: Oxford University Press.

Leighton, Robert. 2005. "Later prehistoric settlement patterns in Sicily: old paradigms and new surveys". European Journal of Archaeology 8 (3): 261-287.

Leone, Anna, Robert Witcher, Francesco Privitera and Umberto. 2007. “The Upper Simeto Valley Project”. In: Fitzjohn 2007: 49-58.

Malfitana, Daniele and Giuseppe Cacciaguerra, eds. 2011. Priolo romana, tardo romana e medievale. Monografie dell'Istituto per i Beni Archeologici e Monumentali, CNR 4. Catania: IBAN.

Malfitana, Daniele and Michel Boniday, eds. 2016. La ceramica africana nella Sicilia Romana / La ceramique africaine dans la Sicile romaine. Monografie dell'Istituto per i Beni Archeologici e Monumentali, CNR 12. Catania: IBAM, Centre Camille Jullian.

Manganaro, Giacomo. 1996. "Per una storia della Chora Katanaia". In: Catania Antica, Atti del Convegno della S.I.S.A.C. (Catania 23-24 maggio 1992), edited by Bruno Gentili, 19-59. Pisa: Istituti editoriali e poligrafici internazionali.

Maniscalco, Laura. 2009. Il Neolitico nella valle del Simeto. In: Tra Etna e Simeto, edited by Gioconda Lamagna, 27-48. Catania: Biblioteca della Provincia Regionale di Catania.

Manni, Eugenio. 1981. Geografia fisica e politica della Sicilia antica. Roma: L'Erma di Bretschneider.

Marchi, Maria L.. 2014. "Carta Archeologica d'Italia - Forma Italiae Project: Research Method". In Multi-, inter- and transdisciplinary research in Landscape Archaeology LAC 2014 Proceedings edited by Sjoerd J Kluiving, Gert-Jan Burgers, Jeremia Pelgrom and Corine Tetteroo (DOI 10.5463/lac.2014.42).

Marzano, Annalisa, 2015. "The Variety of Villa Production". In: Ownership and Exploitation of Land and Natural Resources in the Roman World, edited by Paul Erdkamp, Koenraad Verboven, Arjan Zuiderhoek, 187-206, Oxford: Oxford University Press.

May, Keith, Binding, Ceri, Tudhope, Doug and Jeffrey, Stuart, 2012. "Semantic Technologies Enhancing Links and Linked Data for Archaeological Resources". In: 
Revive the Past. Computer Applications and Quantitative Methods in Archaeology (CAA). Proceedings of the 39th International Conference, Beijing, April 12-16, edited by Mingquan Zhou, Iza Romanowska, Zhongke $\mathrm{Wu}$, Pengfei Xu and Philip Verhagen, 1-12. Amsterdam: Pallas Publications.

Mazza, Mario. 1987. "L'economia siciliana tra Impero e Tardo-Impero". In: Contributi per una storia economica della Sicilia, 15-62. Palermo: Fondazione culturale Lauro Chiazzese della Sicilcassa.

Molè Ventura, Concetta. 2008. "L'età antica". In: Catania. Storia, cultura, economia, edited by Fulvio Mazza, 25-76. Soveria Mannelli: Rubbettino Editore.

Monaco, Carmelo, Fabrizio Antonioli, Giorgio De Guidi, Kurt Lambeck, Luigi Tortorici and Vladimiro Verrubbi. 2004. "Tectonic uplift and sea-level change during the Holocene in the Catania Plain (eastern Sicily)". Quaternaria Nova 7, 171-185.

Monaco, Carmelo, Simone Catalano, Giorgio De Guidi, Stefano Gresta, Horst Langher and Luigi Tortorici. 2000. "The geological Map of the Urban Area of Catania (Eastern Sicily): Morphotectonic and Seismotectonic Implications". Memorie della Società Geologica Italiana 55: 425-38.

Montanari, Massimo. 1987. Campagne medievali. Strutture produttive, rapporti di lavoro, sistemi alimentari. Torino: Giulio Einaudi Editore.

Morris, Ian. 2002. "Archaeology and Ancient Greek History". In: Current Issues and the Study of Ancient History, edited by Carol Thomas, 45-67. Publications of the Association of Ancient Historians 7). Claremont: AAH.

Murray, Olivier. 1992. "The ecology and agrarian history of ancient history". Opus 11: 11-23.

Murrieta-Flores, Patricia and Bruno Martins. 2019. "The geospatial humanities: past, present and future". International Journal of Geographical Information Science 33(12), 2424-2429. DOI: 10.1080/13658816.2019.1645336.

Nenci, Giuseppe, and George Vallet, eds. 1990. Bibliografia topografica della colonizzazione greca in Italia e nelle isole tirreniche 8, Pisa-Roma: Scuola Normale Superiore, Ecole Française de Roma, Centre J. Bérard de Napoli.

Nenci, Giuseppe. 1993. "Agrigento e la Sicilia nel quadro dei rifornimenti granari del mondo greco". Annali della Scuola Normale Superiore di Pisa, Classe di Lettere e Filosofia 23: 1-7.

Orton, Clive. 1993. "How many pots make five? An historical review of pottery quantification", Archaeometry 35 (2): 169-184.

Orton, Clive and Michael Hughes, 2013. Pottery In Archaeology (2nd Edn). Cambridge: Cambridge University Press.

Patanè, Andrea and Graziella Buscemi Felici. 1997-1998. "Scavi e ricerche a Catania, Licodia Eubea, Grammichele, Ramacca”. Kokalos 63-64 2(1): 189-231.

Pfuntner, Laura. 2019. Urbanism and Empire in Roman Sicily, Austin: University of Texas Press.

Prag, Jonathan, R.W. 2015. "Cities and civic life in late Hellenistic Roman Sicily (with an appendix on Cicero, In Verrem 3.12-13 and the status of cities in Sicily after 210 BC)". Cahiers du Centre Gustave Glotz 25: 165-208. 
Prag, Jonathan, R.W. and James Chartrand. 2018. "I. Sicily: Building a Digital Corpus of the Inscriptions of Ancient Sicily". In Crossing Experiences in Digital Epigraphy, edited by A. De Santis and I. Rossi, 240-252. Warsaw: De Gruyter Open). DOI: https://doi.org/10.1515/9783110607208-020.

Privitera, Francesco and Umberto Spigo, eds. 2005. Dall'Alcantara agli Iblei, Palermo: Assessorato dei Beni Culturali.

Privitera, Francesco. 1991-1992. "Castel di Iudica: scavi nel centro greco-indigeno sul monte Iudica”. BCA Sicilia 1-2 (2): 26-30.

1988-1989. "Castel di Iudica: esplorazioni nell'abitato e nella necropoli sul monte Iudica". BCA Sicilia 9-19 (3): 85-88.

—. 2005. "Monte Iudica". In: Dall'Alcantara agli Iblei, edited by Francesco Privitera and Umberto Spigo, 108-111. Palermo: Assessorato dei Beni Culturali.

Procelli, Enrico. 1980. "Elementi di topografia urbana e materiali architettonici dalla Montagna di Ramacca". Cronanche di Archeologia 19: 135-44.

_. 1989. "Aspetti e problemi dell'ellenizzazione calcidese nella Sicilia orientale". Mélanges de l'École française de Rome - Antiquité 101: 679-789.

Richards, Julian D. 2018. "Archaeology Data Service (ADS)". In Encyclopaedia of Global Archaeology, edited by Clair Smith. Cham: Springer. Doi: https://doi. org/10.1007/978-3-319-51726-1_2121-2.

Richards, Julian D., and Niccolucci, Franco. 2019. "ARIADNE and ARIADNEplus". In: The ARIADNE Impact, edited by Julian Richards and Franco Niccolucci, 7-25. Budapest: Archaeolingua. (doi.org/10.5281/zenodo.3476712).

Richards, Julian and Niccolucci, Franco, eds., 2019. The ARIADNE Impact. Budapest: Archaeolingua. (doi.org/10.5281/zenodo.3476712).

Roberts G. 1994. "The Cultural Landscape”. Landscape Research 19 (1): 33-36.

Sfacteria, Marco. 2018. Un approccio integrato al problema della ricostruzione della viabilità romana in Sicilia. La via Catania-Agrigento. BAR 2883. Oxford: Archaeopress.

Sfameni, C. 2018. "Spazi del lavoro e della produzione nelle ville e in altri contesti abitativi della Sicilia tardoantica: considerazioni a partire da ricerche recenti". Amoenitas 7: 83-113 (DOI: 10.19272/201812301005).

Simon, Rainer, Elton Barker, Leif Isaksen and Pau de Soto Cañamares. 2015. "Linking Early Geospatial Documents, One Place at a Time: Annotation of Geographic Documents with Recogito". e-Perimetron 10 (2): 49-59.

Sirena, Giuseppina. 2011. Via Pompeia. L'antico tracciato tra Messina e Siracusa. Catania: Bonanno Editore.

Sirena, Giuseppina. 2012. "La viabilità antica ai margini occidentali della Piana di Catania”. Topografia Antica. Tradizione, tecnologia e territorio 1: 45-56.

Snodgrass, Anthony. 2002. "A Paradigm Shift in Classical Archaeology?”. Cambridge Archaeology Journal 12: 179-94.

Soraci, Cristina. 2011. Sicilia Frumentaria. Il grano siciliano e l'annona di Roma. Roma: L'Erma di Bretschneider. 
Tempio, Antonio. 2014. "Hybla, Inessa e la synteleia duceziana”. Sicilia Antiqua 11: 453-67.

Terranato, Nicola 2004. "Sample Size Matters! The Paradox of Global Trends and Local Surveys". In: Side-by-side survey: comparative regional studies in the Mediterranean World, edited by Susan E. Alcock and John F. Cherry, 36-48. Oxford: Oxbow.

Thompson, Stephen M. 1999. “A Central Sicilian Landscape: Settlement and Society in the Territory of Ancient Morgantina (5000 BC - AD 50)". PhD diss., University of Virginia.

Todaro, Simona V. 2019. "From scatters of pottery to communities?: a view from Phaistos". Thiasos 8: 3-21.

Tortorici, Edoardo. 2002. "Contributi per una carta archeologica subacquea della costa di Catania”. Archeologia Subacquea. Studi, ricerche e documenti 3: 275-334.

- 2006. "Nuovi dati dalla Sicilia Orientale: ricognizioni subacquee a Capo Mulini ed Acitrezza". Journal of Ancient Topography 16: 129-42.

. 2015. "Catania antica: territorio costiero ed entroterra produttivo". Orizzonti 16: $23-30$.

- 2016. Catania antica. La carta archeologica. Roma: L'Erma di Bretschneider.

Tortorici, Edoardo and Rodolfo Brancato. Carta Archeologica della valle dell'Aci. Catania, in press.

Traina, Giusto. 1985. "Antico e moderno nella storia delle bonifiche italiane". Studi Storici 16 (2): 431-436.

1986. "Paesaggio e 'decadenza'. La palude nella trasformazione del mondo antico". In: Società romana e impero tardoantico 3, edited by Andrea Giardina. 711-30, 905-17. Roma-Bari: Laterza.

Tréziny, Henri. 1999a. "Le fortifications greques en occidente à l'epoque classique (491-322 a.C.)". Pallas $51: 241-282$.

. 1999b. "Le fortification indigènes et fortifications greques dans l'Occident grec". In: Grecs et indigénes dela Catalogne à la mer Noire, edited by in Henri Tréziny, 557-66. Errance: Centre Camille Jullian.

Uggeri, Giovanni. 2004. La viabilità della Sicilia in Età Romana. Galatina: Congedo Editore.

Valenti, Francesco. 1992. Lestrigonia. Insediamenti preistorici nel territorio dell'antica Leontini. Catania: CUECM.

—. 1997-1998. "Note preliminari per lo studio degli insediamenti di Età Romana a Sud della Piana di Catania". Kokalos 63-64 2 (1): 233-74.

Vera, Domenico. 1999. "Massa fundorum. Forme della grande proprietà e potere delle città in Italia fra Costantino e Gregorio Magno". Mélanges de l'École française de Rome. Antiquité 111 (2): 991-1025.

_. 2018. "Horrea e trasporti annonari in Africa e a Roma fra Costantino e Genserico: una complessa organizzazione integrate". In: Entrepôts et circuits de distribu- 
tion en Méditerranée antique, edited by Véronique Chankowski, Xavier Lafon and Catherine Virlouvet, 61-92. Athens: Ecole Française d'Athènes.

Verhagen, Philip. 2018. "Spatial Analysis in Archaeology: Moving into New Territories". In: Digital Geoarchaeology. Natural Science in Archaeology, edited by Christoph Siart, Markus Forbriger and Olaf Bubenzer, 11-25. Cham: Springer.

Vermeulen, Frank. 2012. "The integration of survey, excavation, and historical data in northern Picenum". In: Comparative Issues in the Archaeology of the Roman Rural Landscape. Site Classification Between Survey, Excavation and Historical Categories, edited by Peter A.J. Attema and Günter Schörner, 43-53 (JRA Suppl. 88).

Volpe, Giuliano. 2007. “L'archeologia globale per ascoltare la storia totale del paesaggio”. In: Sudest 20: 20-32.

- 2016. Il paesaggio negato: per un approccio integrato alla marginalità. In: Storia e Archeologia globale 2, edited by Franco Cambi, Giuliano De Venuto, Roberto Goffredo, 325-330. Bari: Edipuglia.

Whaltall, Alex. 2011. "Magistrate Stamps on Grain Measures in Early Hellenistic Sicily". Zeitschrift für Papyrologie und Epigraphik 179: 159-69.

Wilkinson, Tony. J. 2003. Archaeological Landscapes of the Near East. Tucson, AZ: The Arizona University Press.

Wilson, Roger J.A. 1987-1988. “Archaeology in Sicily, 1982-1987”. Archaeological Reports 34: 119-20.

1990. Sicily under the Roman Empire. Warminster: Aris \& Phillips.

Witcher, Robert E. 2008. "(Re)surveying Mediterranean Rural Landscapes: GIS and Legacy Survey Data”. Internet Archaeology 24, 2008. DOI 10.11141/ia.24.2

Wright, Holly. 2018. "Semantic Web and Ontologies". In: The Encyclopedia of Archaeological Sciences edited by Sandra L. López Varela. Hoboken: Wiley-Blackwell. (doi.org/10.1002/9781119188230.saseas0527).

Wright, Holly and Gabriele, Gattiglia. 2018. "ArchAIDE: Archaeological Automatic Interpretation and Documentation of cEramics". In: CIRA@EuroMed 2018 Engineering, Computer Science. (http://ceur-ws.org/Vol-2235/paper7.pdf).

Wright, Holly and Richards, Julian D. 2018. "Reflections on Collaborative Archaeology and Large-Scale Online Research Infrastructures". Journal of Field Archaeology 43 (1): S60-S67. (https://doi.org/10.1080/00934690.2018.1511960).

Zambito, Luca. 2014 "Estrazione e raffinazione dello zolfo e paesaggio nella Sicilia romana tra IV e VI d.C.". In: Multi-, inter- and transdisciplinary research in Landscape Archaeology LAC 2014 Proceedings edited by Sjoerd J Kluiving, Gert-Jan Burgers, Jeremia Pelgrom and Corine Tetteroo. DOI 10.5463/lac.2014.7. 